قر اءات ومر اجعات

\title{
قراءة في كتاب \\ نقد الأديان عند ابن حزم الأندلسي \\ ت* تأليف: عدنان المقراني
}

***

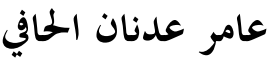

يقدم هذا الكتاب إضافة نوعية في دراسة الأديان ونقدها من منظــــور إســلامي

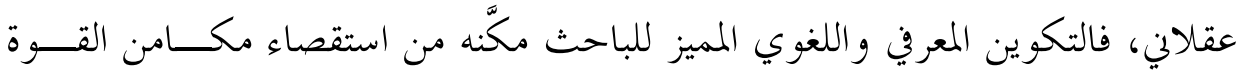

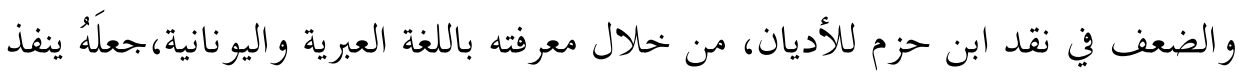

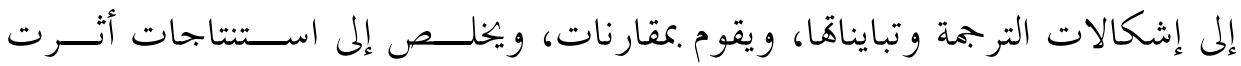
الدراسة العلمية النقدية للنصوص الكتابية.

كما أظهر الكتاب مدى تأثير ما استجد من تطورات معرفية كــبيرة، في بحـــال

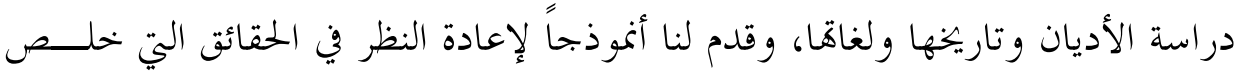

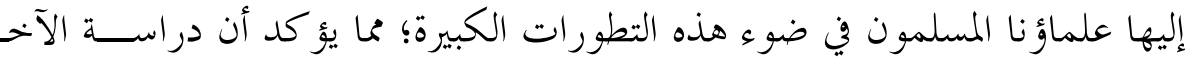

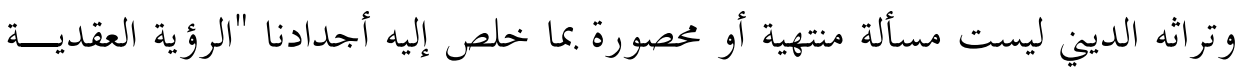

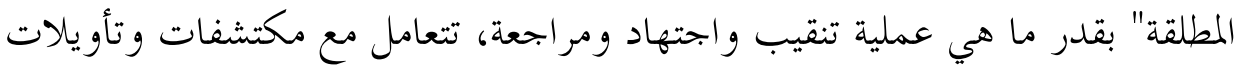

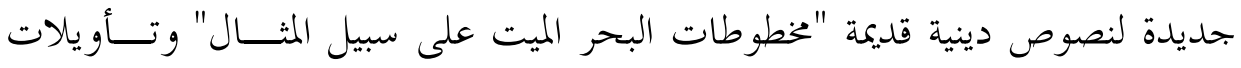

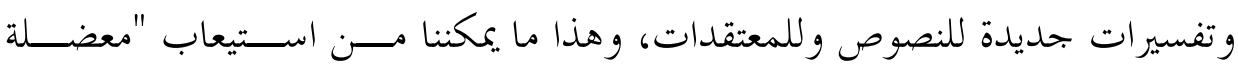

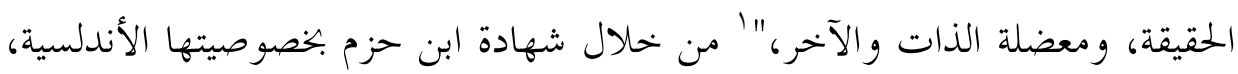

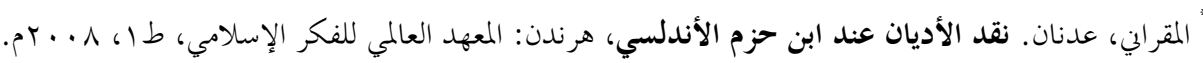

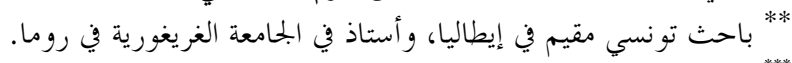

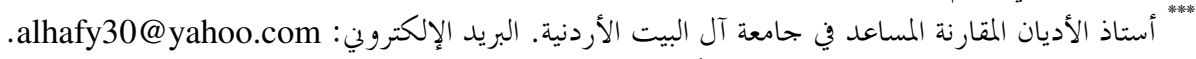

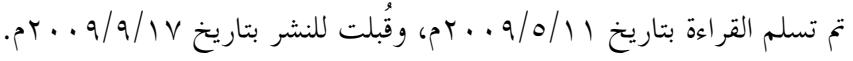

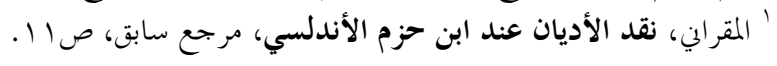


التي درست نصوص اليهودية والمسيحية والأديان الشرقية وعقائدها دراسة تفكيكيــة المبـات

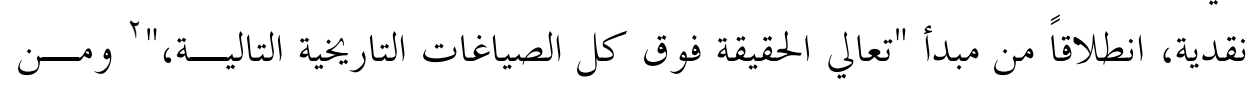

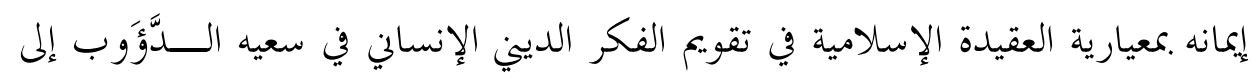
معرفة الحقيقة.

ينطلق الكاتب في مقدمة كتابه من تصنيف الابتحاهات الإسلامية الــتي صــاغت

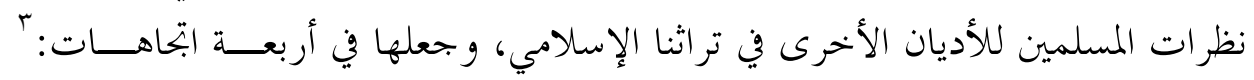

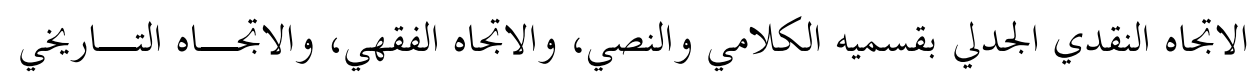

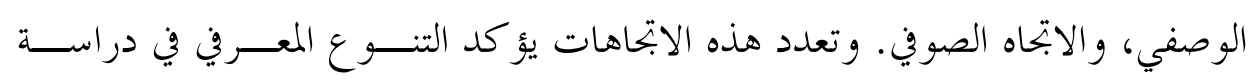

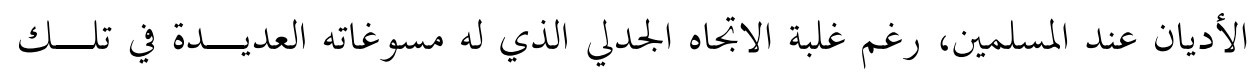
المر حلة.

لم تقتصر دراسة الأديان في التراث الإسلامي على ما دُوّن في كتب الملل والنحل

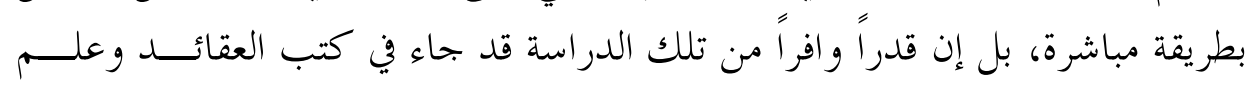

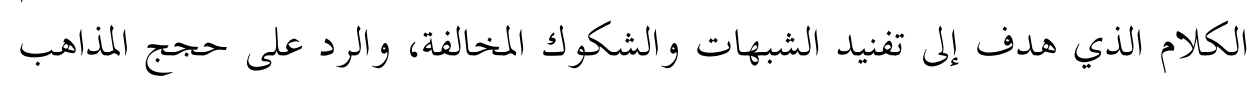

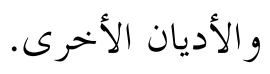

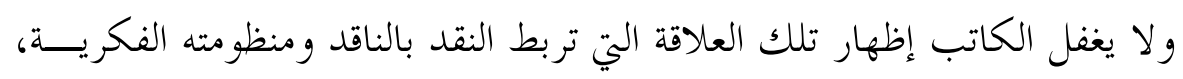

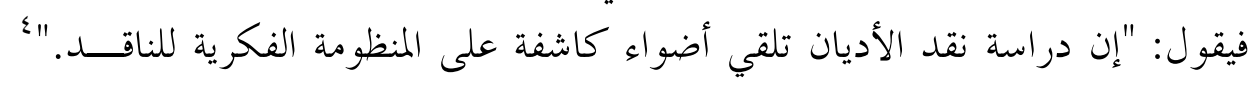

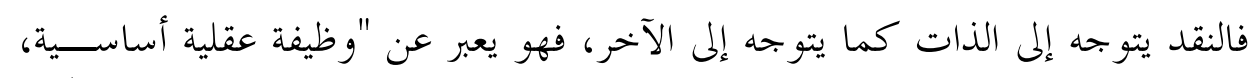

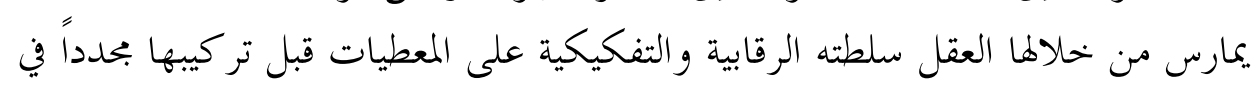

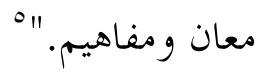

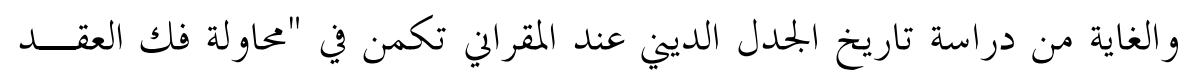

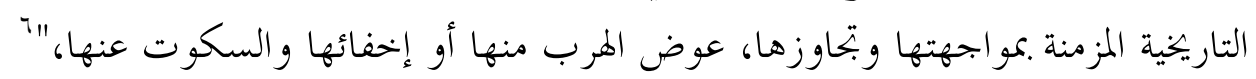




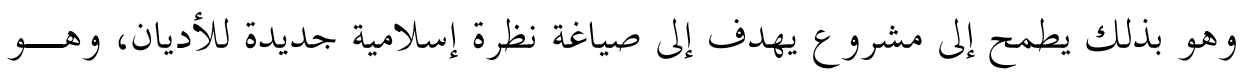

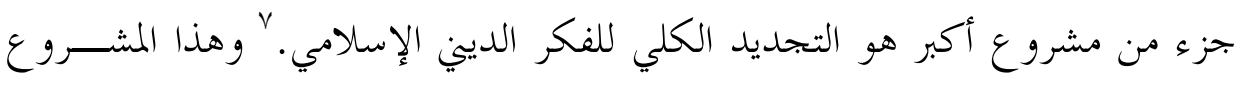

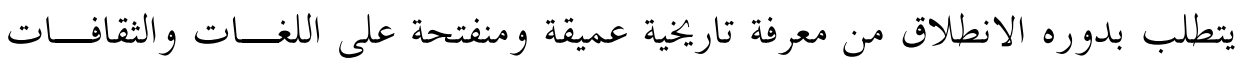

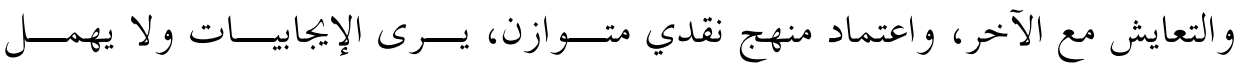

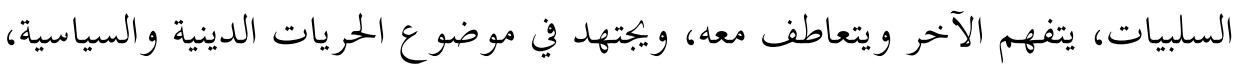

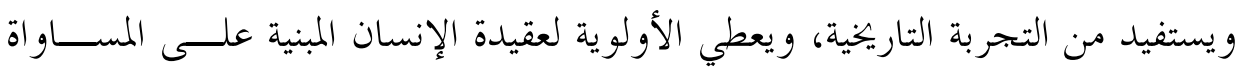

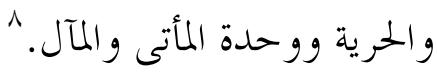

وبوعي عميق يدرك الكاتب ما ينطوي عليه البحث في بحال الأديان من صــوبة

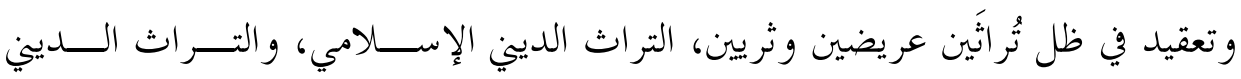
المسيحي، ويدرك سهولة الوقوع ضحية لإسقاط المفاهيم الذاتية ومعاييرها على الآخر،

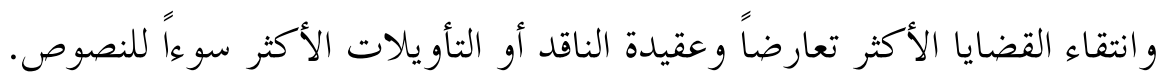
وتأتي دراسة فكر ابن حزم خطوة أولية في مشروع علاقـــة المســلمين بــالآخر

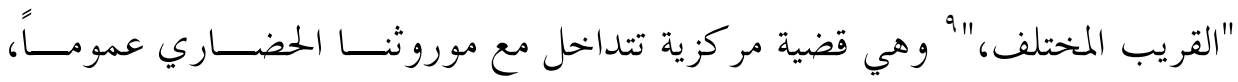

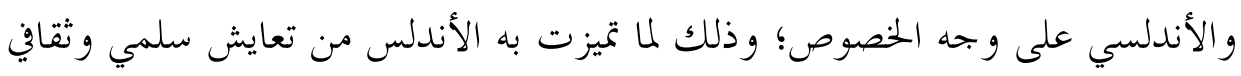

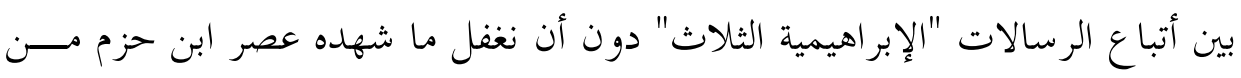

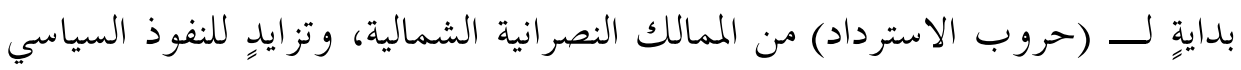

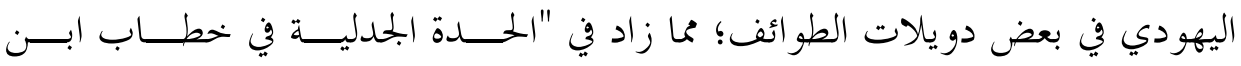

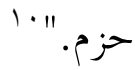

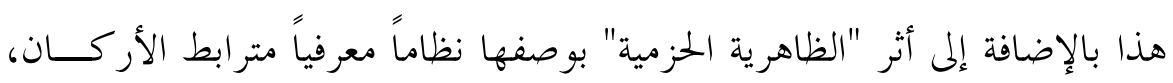

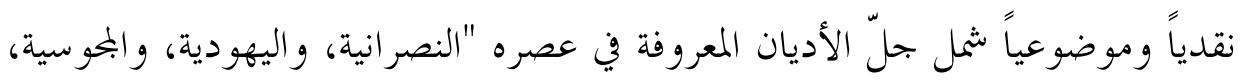

$$
\begin{aligned}
& \text { " المرجع السابق، صلا لا. }
\end{aligned}
$$

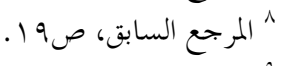

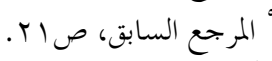

$$
\begin{aligned}
& \text { '' المرجع السابق، صباق، صلr. }
\end{aligned}
$$




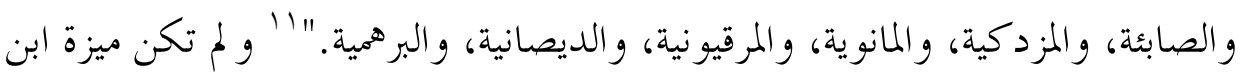

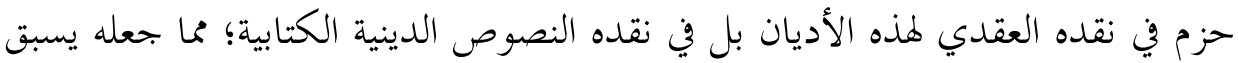

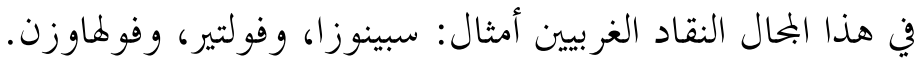

وتتلخص أهداف هذه الدراسة بوضع نقد ابن حزم ضـــمن ســياقه التــاريخي

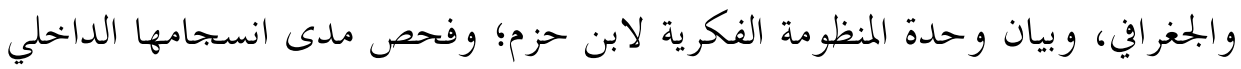

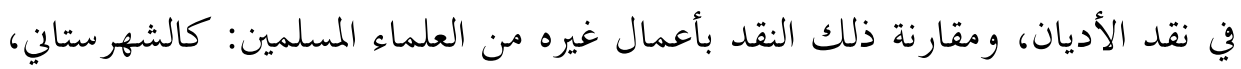

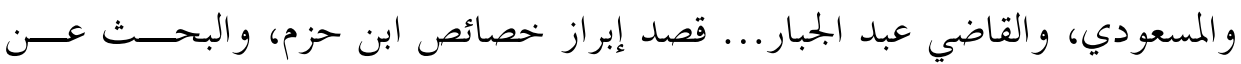

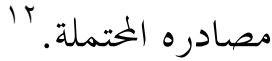

تناول الكتاب في مدخله العام عصر ابن حزم وحياته وفكره، وأوضح ما اشــتمل

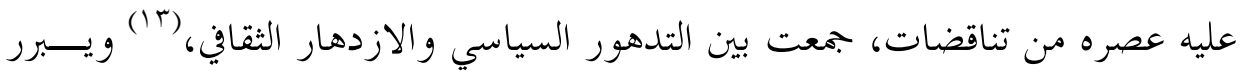

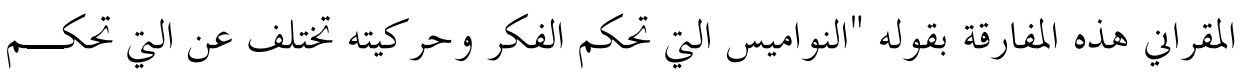

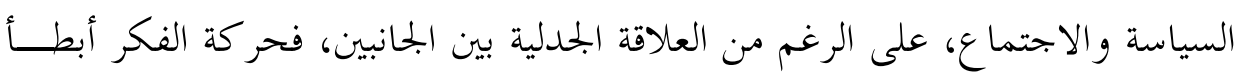

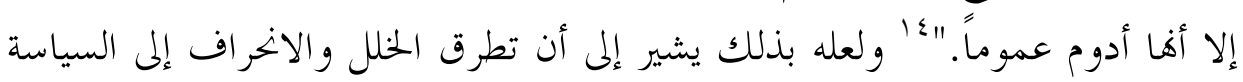

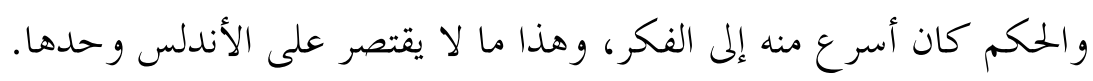

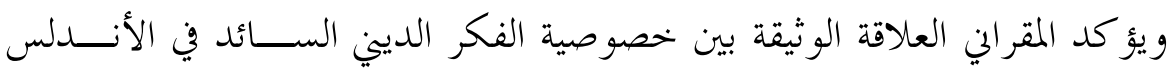

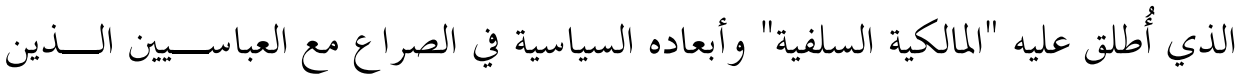

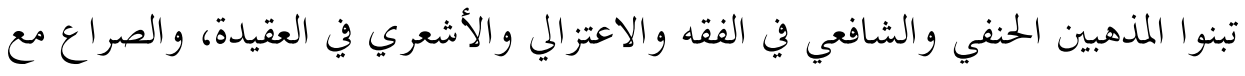
الفاطميين الذين ينتسبون للمذهب الشيعي الإسماعيلي. واستعرض الكاتب أحوال النصارى في الأندلس وانقسامهم إلى: نصارى ذِذََّسيين عاشوا تحت رعاية الدولة الإسلامية، ونصارى محار بين (الممالك النصرانية الشـــمالية).

$$
\begin{aligned}
& \text { "' المرجع السابق، صبات. } \\
& \text { r' "المرجع السابق، صهr. }
\end{aligned}
$$

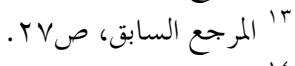

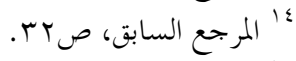

$$
\begin{aligned}
& \text { •" المرجع السابق، صبrاته. }
\end{aligned}
$$


وأما أحوال اليهود الأندلسيين الذين عانوا من الاضطهاد على يد القوط في فاية القرن

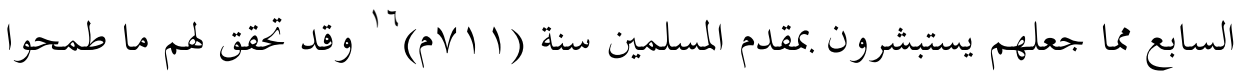

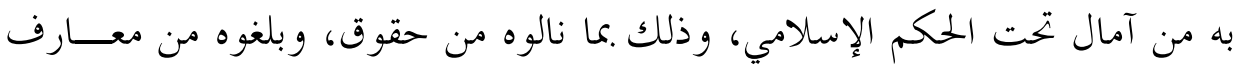

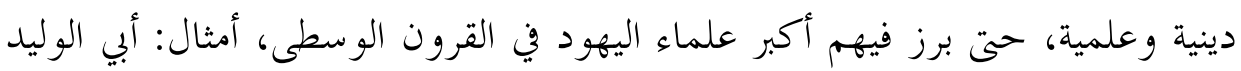
القرطبي، وابن جبرول، وابن فاقوذا، وابن النغريلة.

وأما حياة ابن حزم فقد ركز الكاتب على جانبها العلمي، وذكر أبــرز شــيوخه

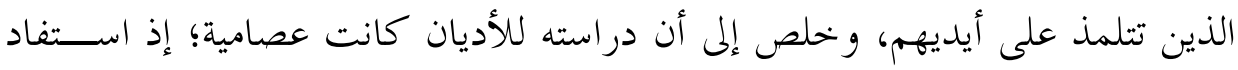

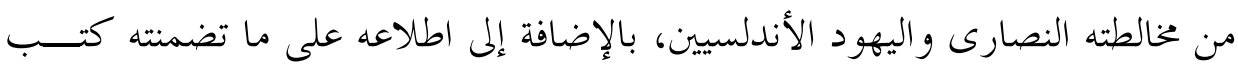
المتكلمين المشارقة من قضايا تخص نقد الأديان. وفي دراسة الكاتب لمؤلفات ابن حزم في نقد الأديان، بخده قد اهتم بثلاثةِ كتـــبـ

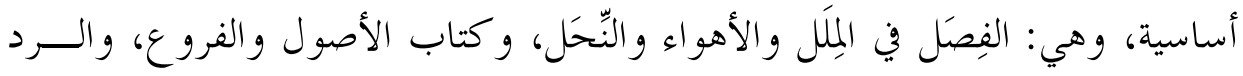

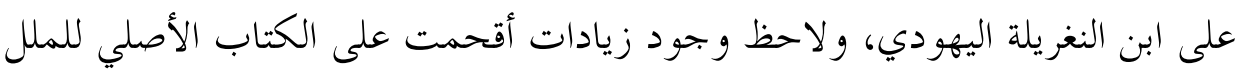

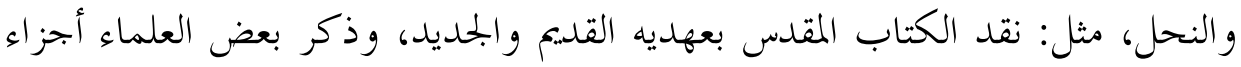

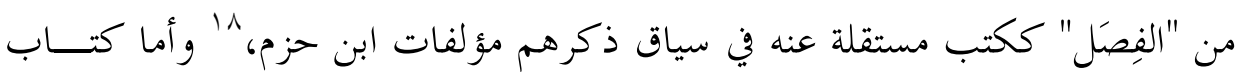

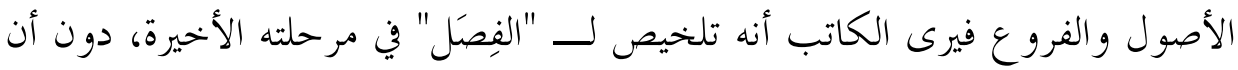

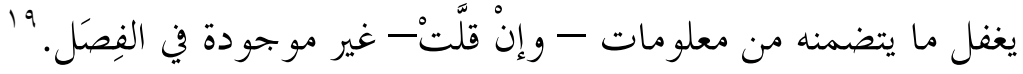
وأما كتابه الثالث "رسالة في الرد على ابن النغريلة" فبعد أن يبحــث المقـــــاني في

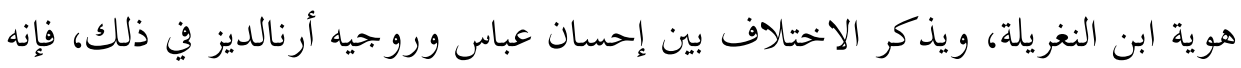

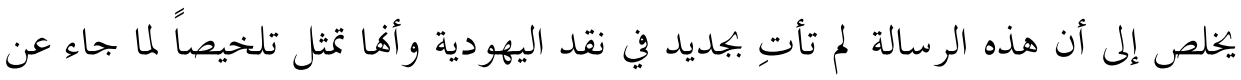

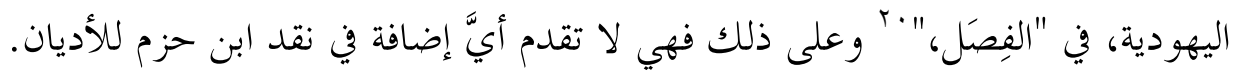

$$
\begin{aligned}
& \text { 7" المرجع السابق، ص اعـ. }
\end{aligned}
$$

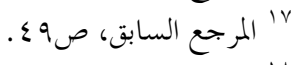

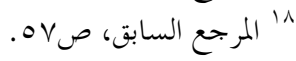

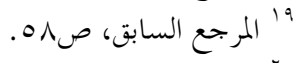

$$
\begin{aligned}
& \text { •r المرجع السابق، صعاب، صـاه. }
\end{aligned}
$$




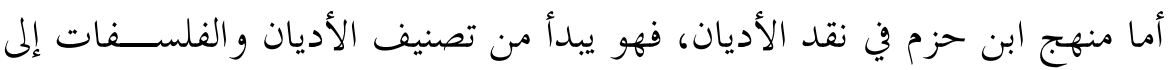

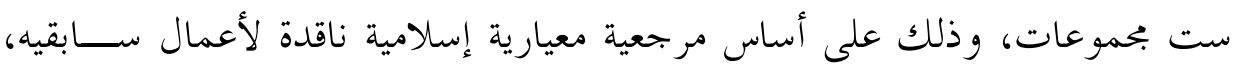

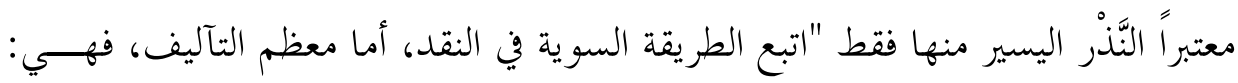

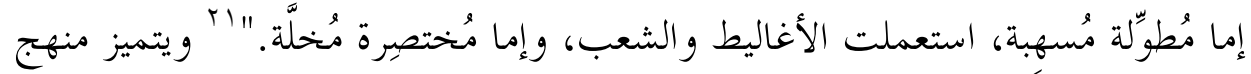

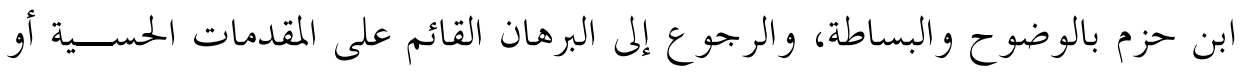

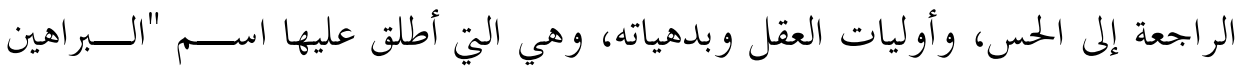

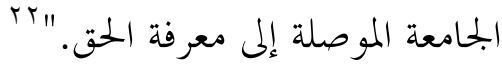

ولم يذكر ابن حزم عند استعراضه لمعايير النقد المرجعية الإسلامية مباشـــــ؛ لأن

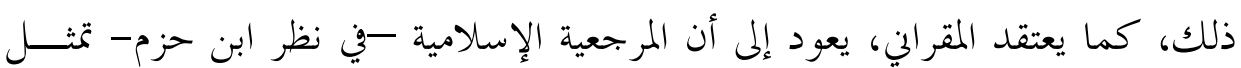

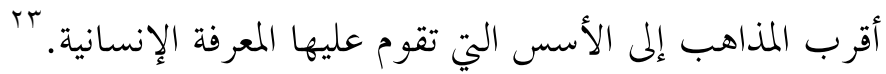

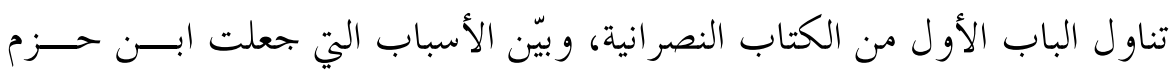

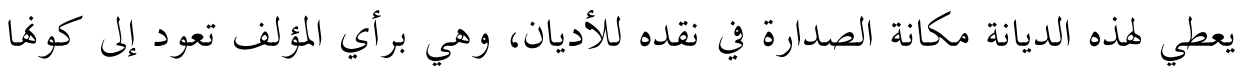

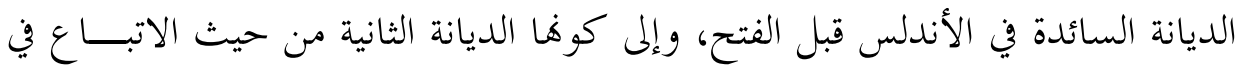

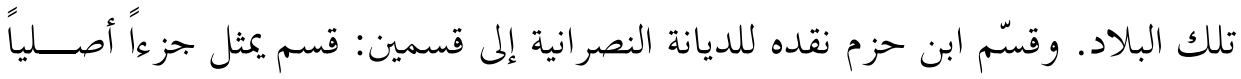

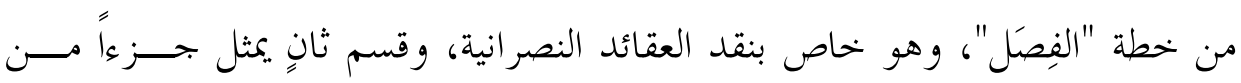

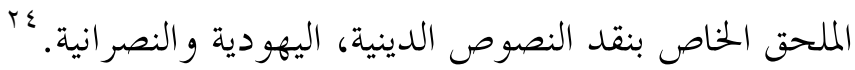

وقد عَرَّفَ ابن حزم بالفِرَق النصر انية قبل نقدها، وقسَّمها صنفين: الأول ذكــــهـ

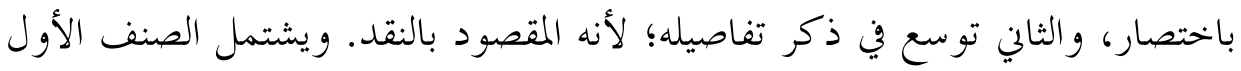

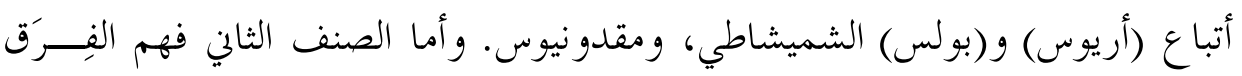

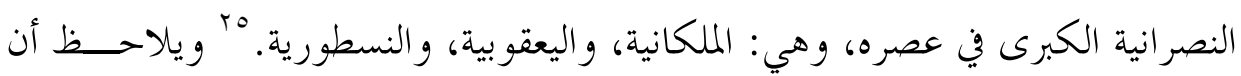

$$
\begin{aligned}
& \text { اr المرجع السابق، صی؟T. }
\end{aligned}
$$

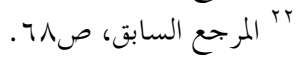

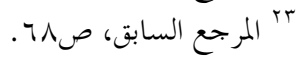

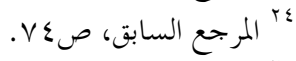

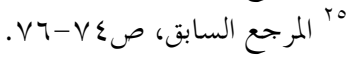


ابن حزم قد صاغ العقائد النصرانية بطريقة تبرز "التناقضات" التي تحتويها في نظـــه،

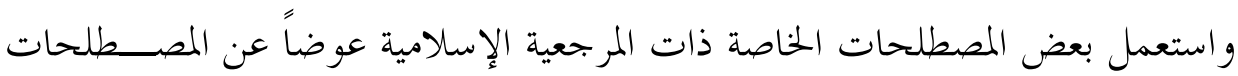
المسيحية.

بدأ ابن حزم بنقد عقيدة التثليث -مثله مثل بقية النقاد المسلمين- إذ إنَّها أول ما يتصادم في نظرهم و النظرة الإسالامية للتوحيد. وقد اشتمل نقده على مبادئ و اضــحة

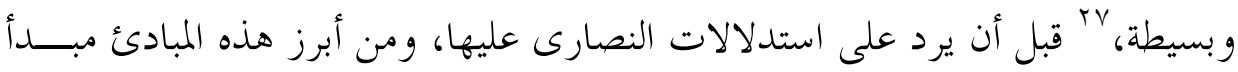

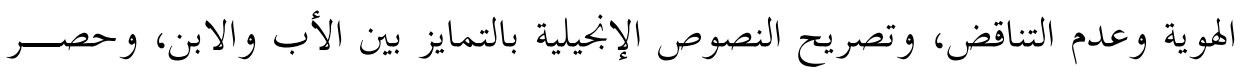
الأقانيم في ثلاثة؛ مما يقتضي التركيب، ومن ثمة الحمدوث.

وأما نقد الاستدلالات النصرانية العقلية على عقيدة التثليث فقد رد ابن حزم على

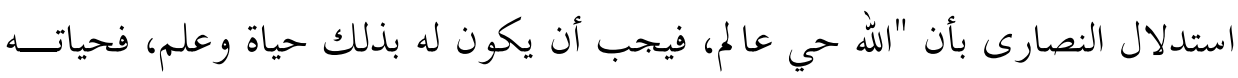

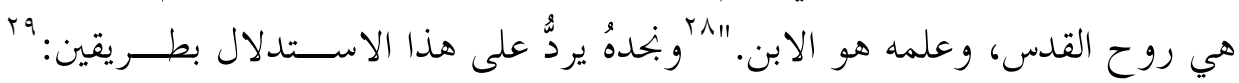

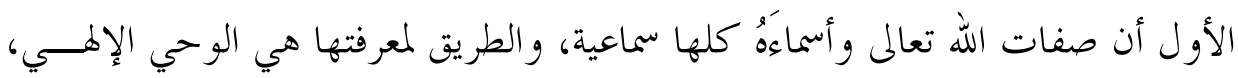
و الإبجيل يخلو من أي وصف لعلم الله بأنه ابنه. و الطريق الثاني: هو برفض قياس الغائب

$$
\text { (الله) على الشاهد (العالم). }
$$

و وفي رده على عقيدة الاتحاد و التجسد التي تعني عند النصارى "بأن أُقنـــوم الابـــن

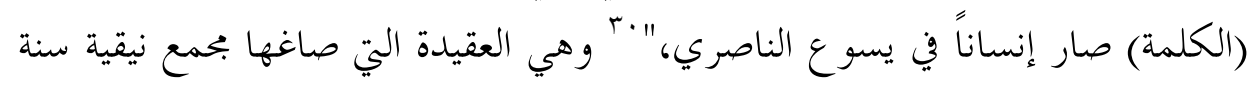

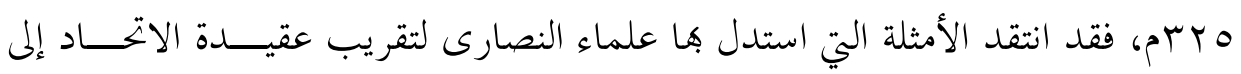

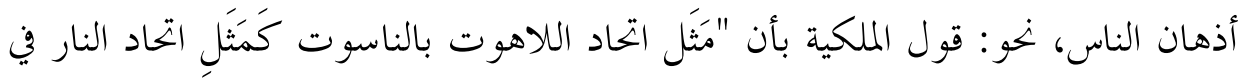

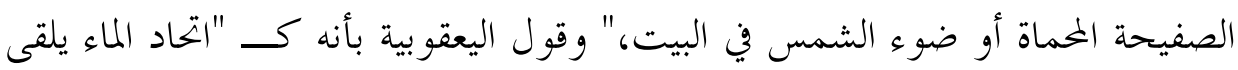

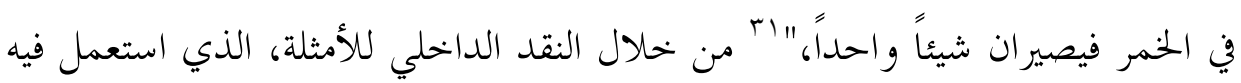

$$
\begin{aligned}
& \text { rr المرجع السابق، ص99. }
\end{aligned}
$$

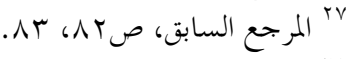

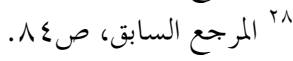

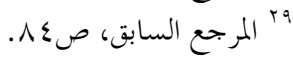

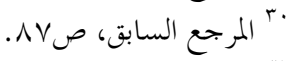

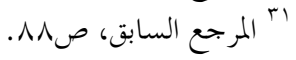




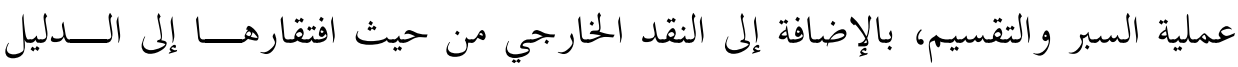
النصي.

و العقيدة الثالثة التي انتقدها ابن حزم تتمثل في "نص الأمانة" الذي صيغ في البحمع

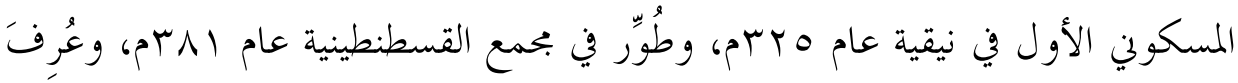

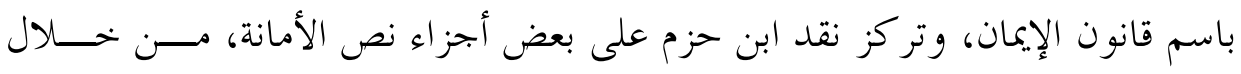

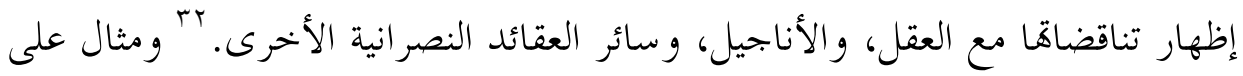

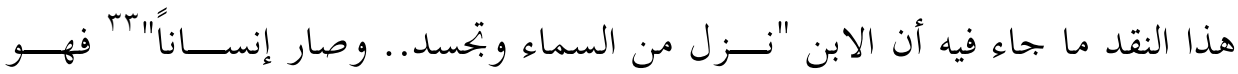

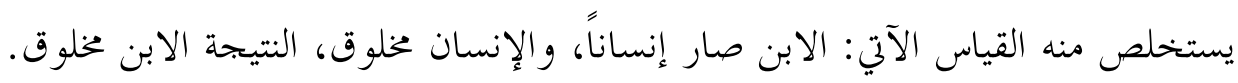

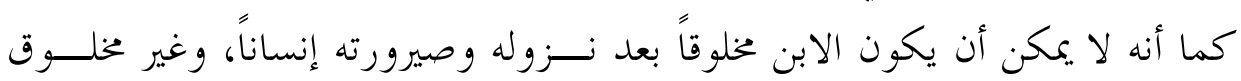

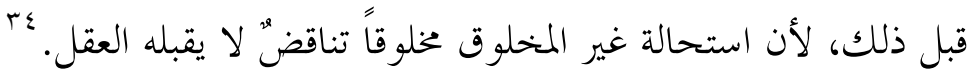

وانتقد ابن حزم تأويل النصارى لبعض آي القر آن؛ لجعلها تشير إلى عقيدة الاتحاد

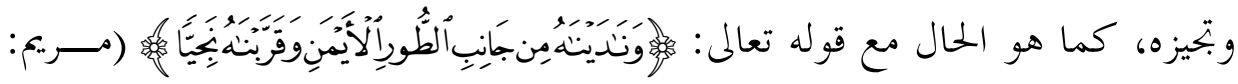

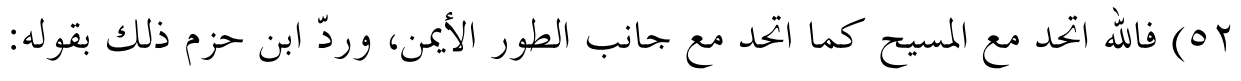

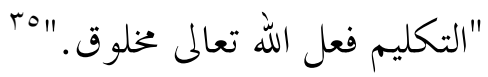

وتميّز نقد ابن حزم لعقيدة الصلب عن نقده لبقية العقائد النصرانية مــن الناحيــة

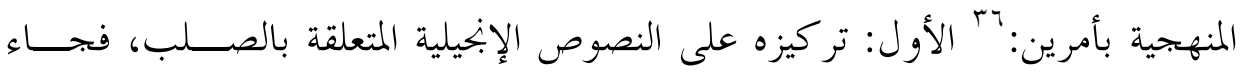

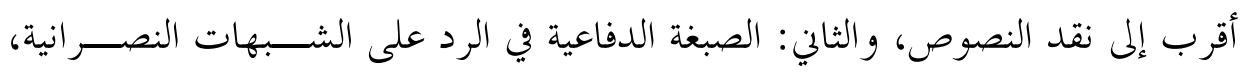

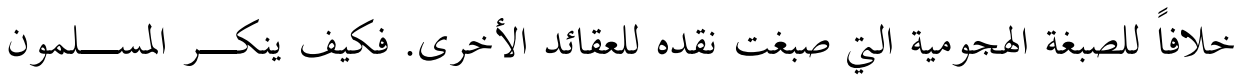

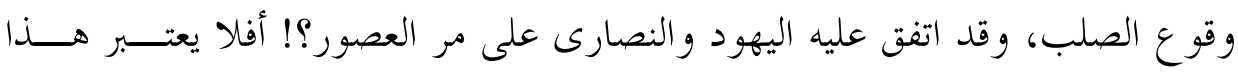

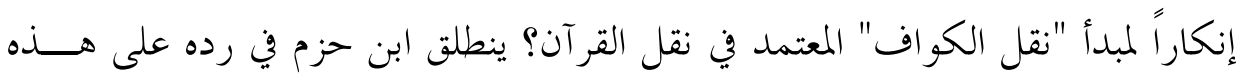

$$
\begin{aligned}
& \text { rrr المرجع السابق، ص. } 9.9
\end{aligned}
$$

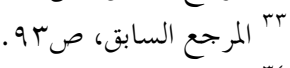

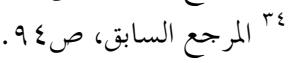

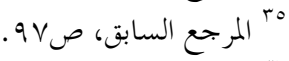

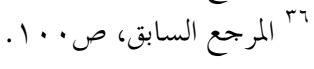




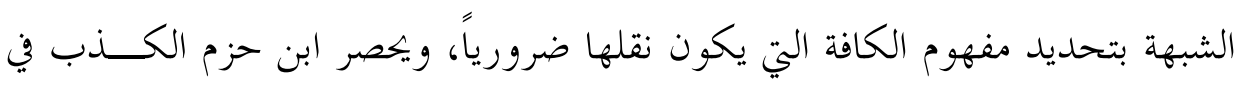
الطبقة الأولى التي روت الخبر.

ومن خلال تحليلٍ أبرز فيه المقرابي الجههد الكبير لابن حزم في دراســـة النصــوص الإبجيلية المتعلقة في الصلب، لا سيَّما ما يتعلق بزمن الصلب ومكانه، وما أحاط بعملية الصلب من الخوف والكتمان، فالظروف المحيطة بالصلب لم تكن تسمح بأن يشـــهـه

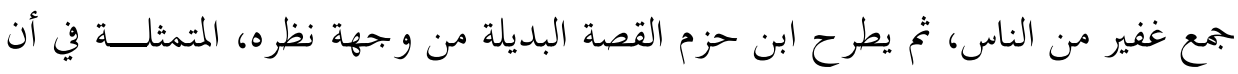
الذين ادََّعَوا شهودهم صلب المسيح، قد صلبوا في الواقع شخصاً آخر، ودفنوه في سرِيّة

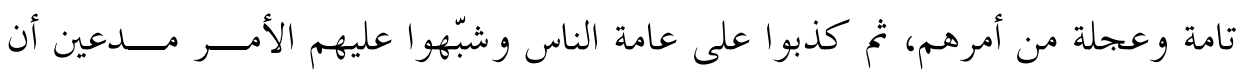
المصلوب هو المسيح.

ويضرب ابن حزم مثلاً على اشتهار الشائعات في التاريخ بقصة دفن المؤيد هشام بن الحكمم، الخليفة الأموي بالأندلس عام (9 . . (م)، و اعتقد الناس موته، و كان ابــن

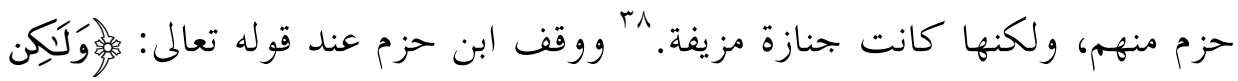

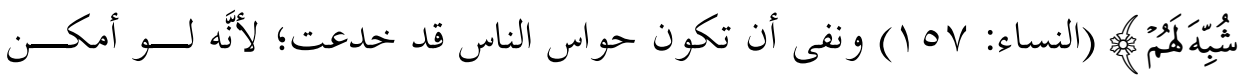

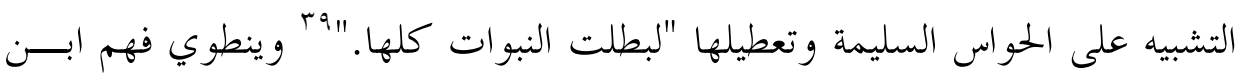
حزم لهذه الآية على رد غير مباشر على التفسير الشائع للآية، الذي يذهب إلى أن الله ألقى شبه المسيح على أحد تلامذته، وهو تلميذه الذي وشى به (يهوذا الاسخريوطي)، وأنه هو الذي صُلِبَ بدلاً منه.

كما ينتقد ابن حزم الشرائع التي يعمل بها النصارى، مثل: صالاهـم، و تعظــيمهم

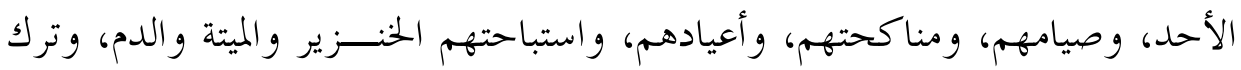

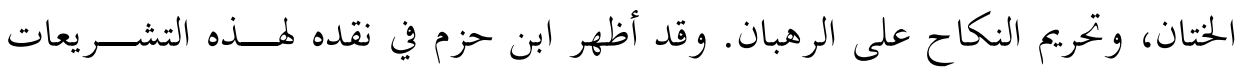

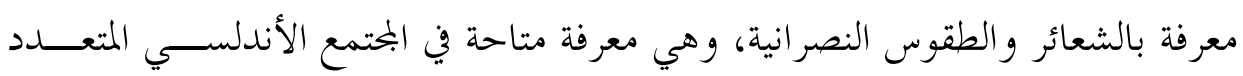




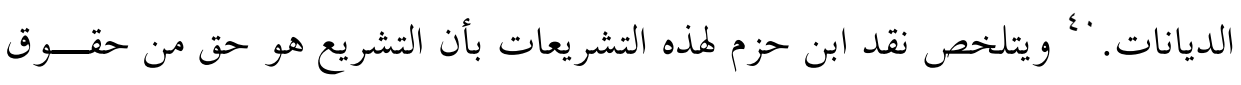

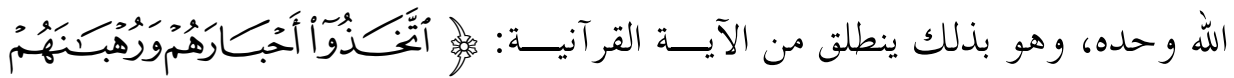

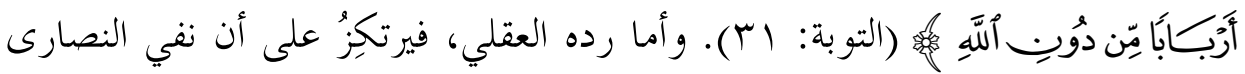

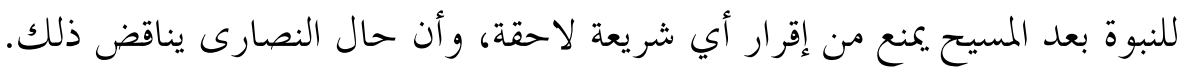
ولا شك أن ابن حزم لم يلتفت إلى تفاوت مفهوم النبوة بين العلمـــاء المســلمين

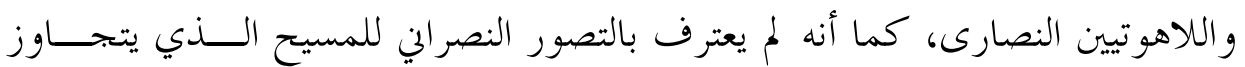

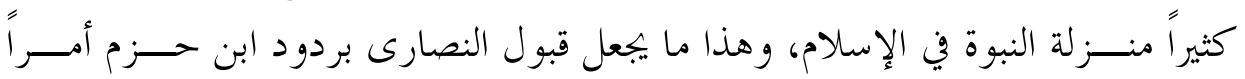

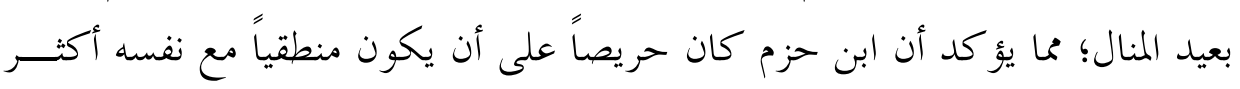
من حرصه على فهم الآخرين.

ويخرج المقراني في فاية عرضه للمعتقدات النصرانية التي انتقدها ابن حزم بملاحظة

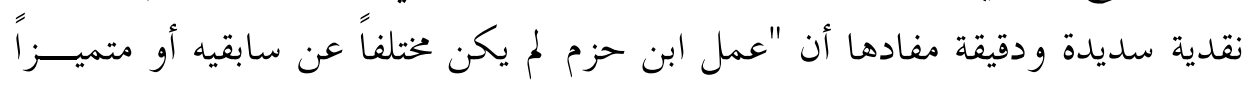

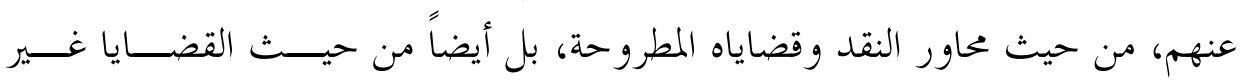

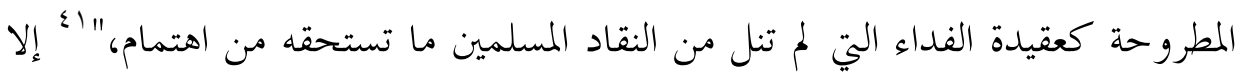

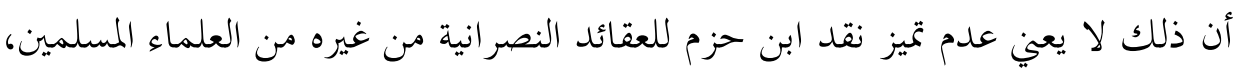

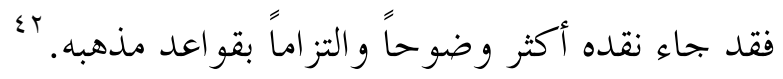

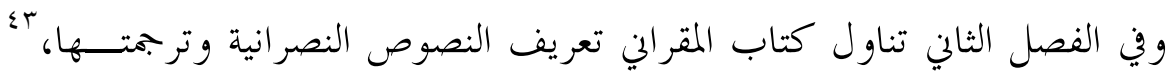

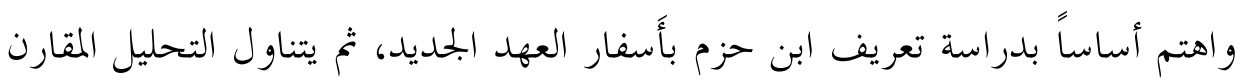

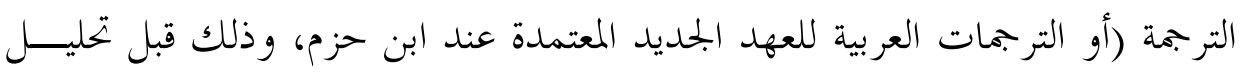

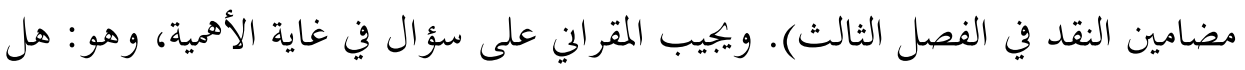

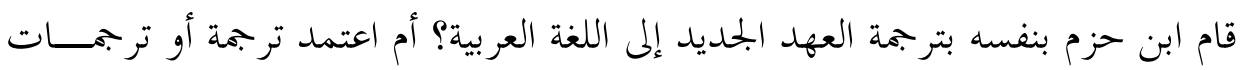
جاهزة؟

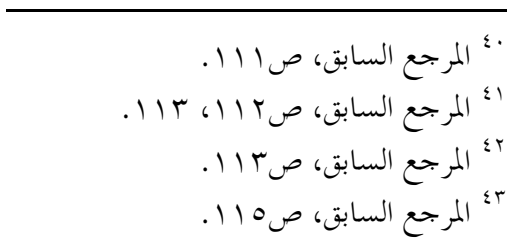


إن الترجمة الوحيدة التي كانت قبل ابن حزم هي ترجمة إســحاق ابــن بلشـــك

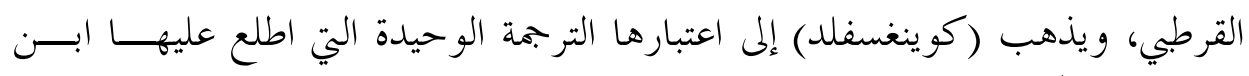

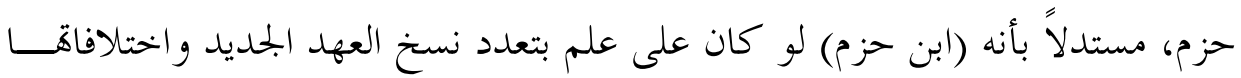

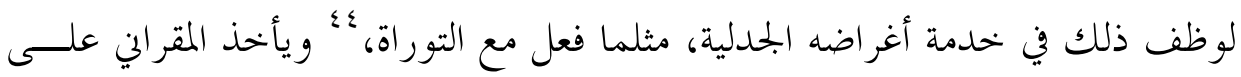

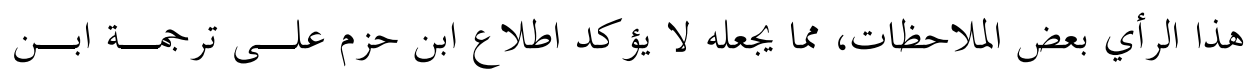
بلشك، و إن كان لا يستبعد حدوث ذلك ذلك.

ويشير الكاتب إلى احتمال آخر لم يسبقه إليه أحد، وهو: للاذا لا يكون ابن حزم

مترجم نصوصه عن اللغة اليونانية؟ ويستدل ببعض القرائن على إمكان ذلك، أهمهـــا: ذكر ابن حزم أن اللغة اليونانية هي لغة أسفار العهد الجحديد، ونقده للترجمة السبعينية، وإدراكه للاختلافات اللغوية بين اللغتين العربية واليونانية: كما يدعم المقـــــاني هـــــا

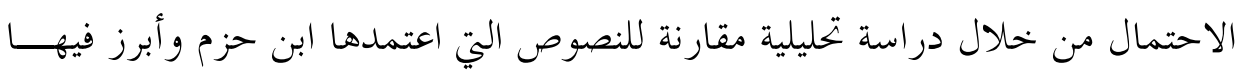

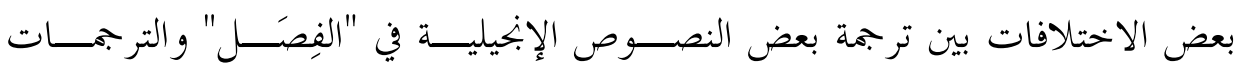

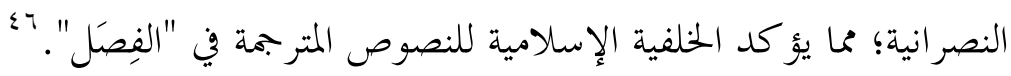

وأفرد الكتاب الفصل الثالث لنقد أسفار العهد الجلديد من حيـــث طــــق ورود

النصوص ونقلها (النقد الخارجي)، ثم (النقد الداخلي)، من حيث فحوى النصــوص و مكامن الخلل والتناقض، بالمقارنة بين النصوص ومعطيات الحو اس وأولويات العقــل و بلديهياته.

استلهم ابن حزم معرفته في علوم الحلديث في صياغة منهجه في نقـــد الروايـــات و النصوص الدينية المسيحية واليهودية، "وما يميز ابن حزم في نقده للأديان الكتابية هو

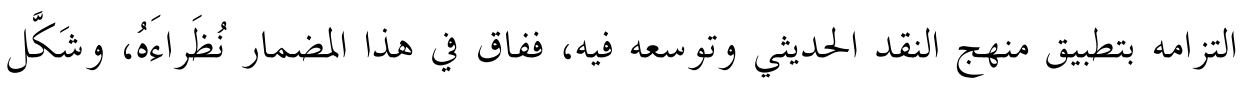

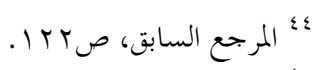

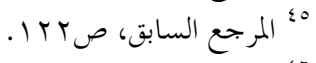

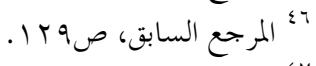

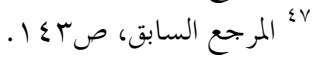




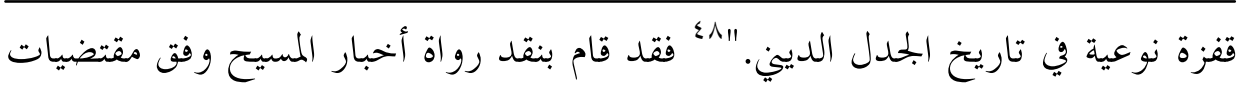

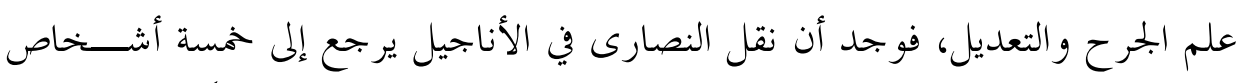

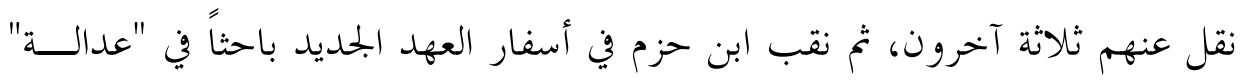

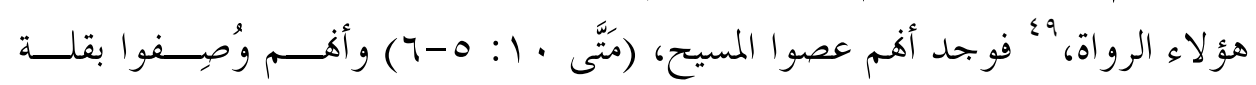

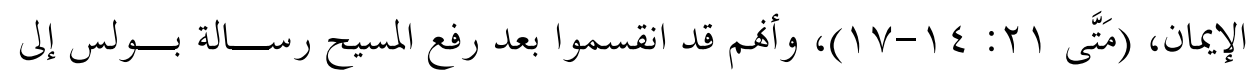

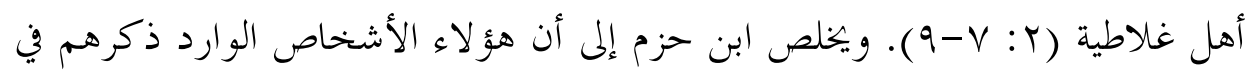

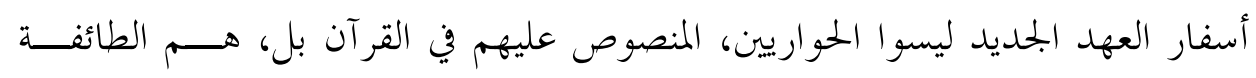

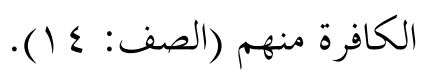
لم يتنبه الكاتب إلى أن ابن حزم لم يتعرض لسبب تسمية النصارى بأهل الكتاب،

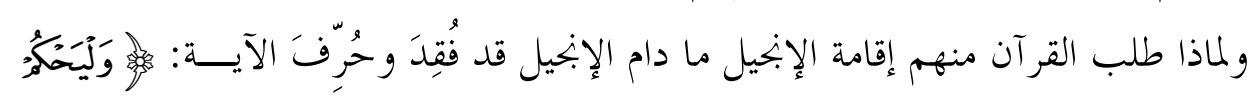

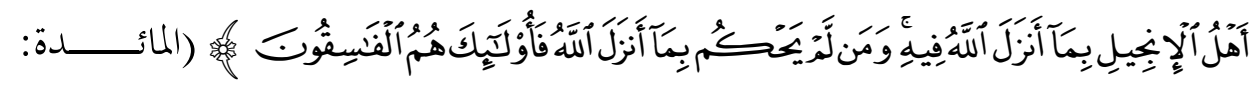

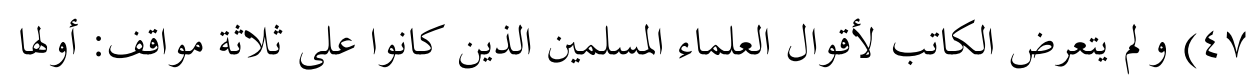

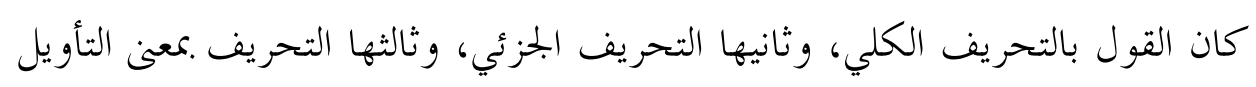

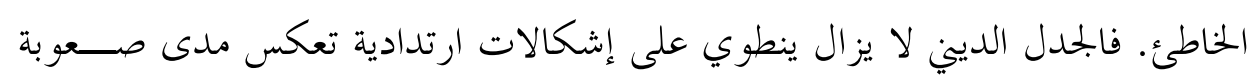
صياغة النقد الديني دون أن تنعكس تلك الصياغة على الناقد ومنظومته العقدية.

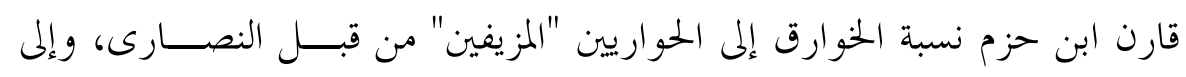

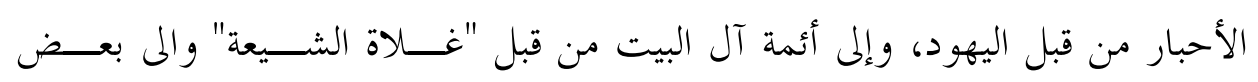

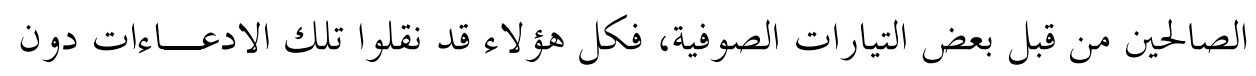

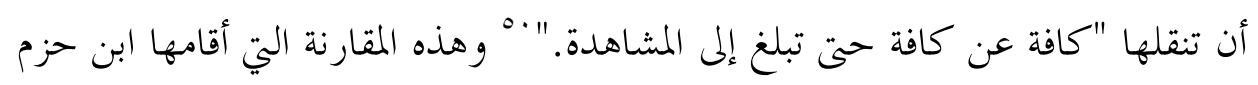

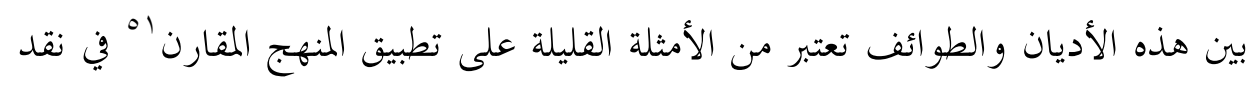

$$
\begin{aligned}
& \text { هـ المرجع السابق، صباء 1. }
\end{aligned}
$$

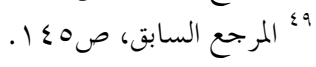

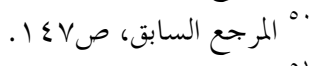

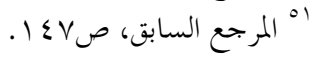


العقائد، خلافاً لتوسعه في نقد النصوص الدينية. ولكي يزيد ابن حزم في إظهار الخلـلـل

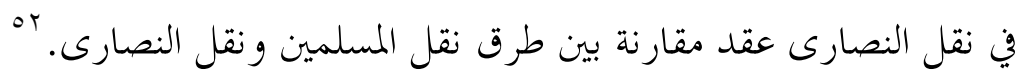

ولكن المقارنة بين هذه الطرق عند ابن حزم لم تأخذ بالحسبان اختلاف مفهـــوم

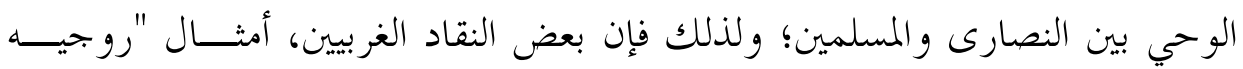

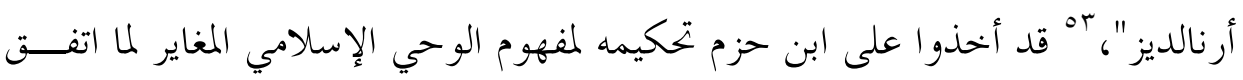
عليه النصارى، وهذا يؤ كد أهمية تحديد المصطلحات و المفـــاهيم في دراســــة الأديـــان

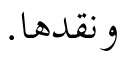

وأما النقد الداخلي للنصوص المسيحية فإن ابن حزم قد قسم نقده للأناجيــل إلى

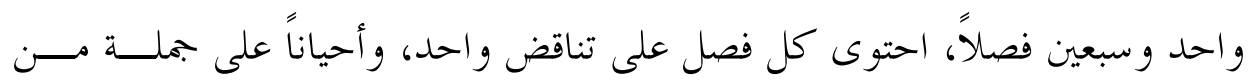
التناقضات الفرعية، وقد "نظر إلى كل إبخيل كسلسلة من القضايا المتعاقبة، تحتمل كل

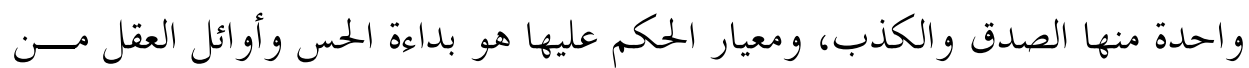
ناحية المصداقية الخارجية، وأما من ناحية المصداقية الذاتية، أي تماسك النصــوص -

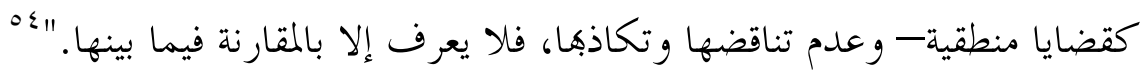
ويعتبر المقراني نقد ابن حزم لأسفار العهد الجحيد "غــير مســبوق في منهجــــ وشموله".

وون خلال استقراء المواضيع التي استدل بها ابن حزم من الأناجيـل و الرســائل

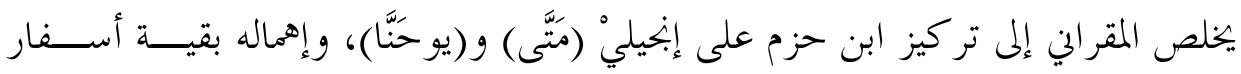

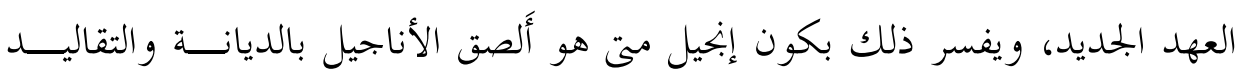

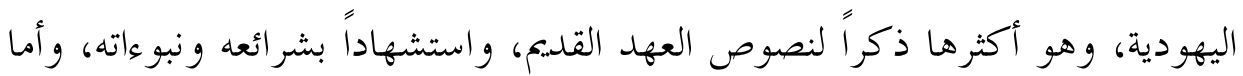




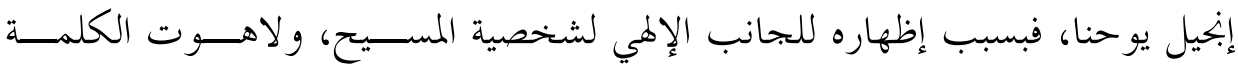
وبتحسدها.

و في سبيل ترتيب المواضيع التي ذكرها ابن حزم في نقده للنصوص الإنجيلية، فقـــــ

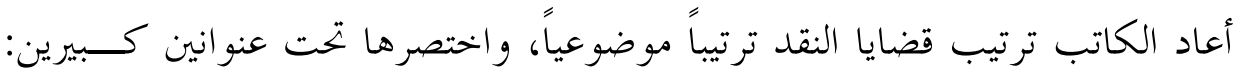

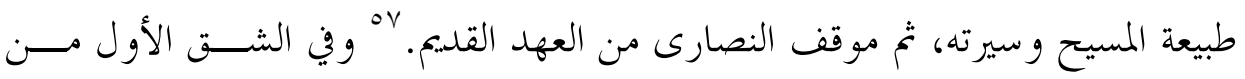
حديثه عن طبيعة المسيح، تحدث عن ناسوت المسيح، و تناول الأخلاق المنسوبة إليــه، ورآها غير لائقة به. ^هم ثم انتقد نسب المسيح في مقارنة ذات ثلاثة مستويات: بين إبنيل

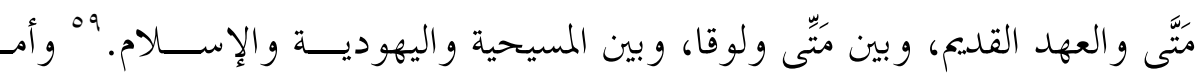
لاهوت المسيح "ألوهية المسيح" فقد سعى ابن حزم إلى البرهنة على عدم تطابق عقائد النصارى ونصوصهم الدينية، وعدم وجود نصوص قطعية الدلالة في هذه المسألة، وبيَّنَ

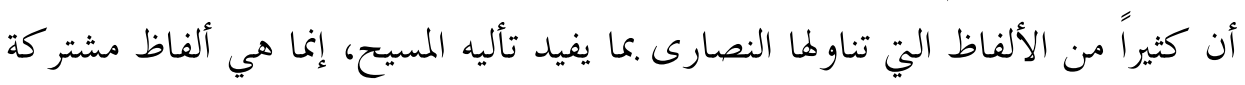
وعامة، وردت بشأن المسيح وغيره من الناس. .7 وخلافاً للغزالي الذي قال .مجازية الألفاظ التي تشير إلى أبوة الله للمسيح، فإن ابن

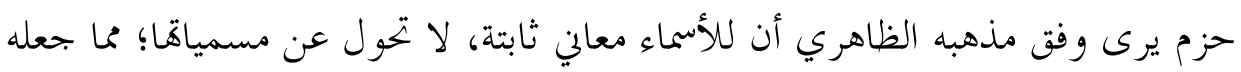

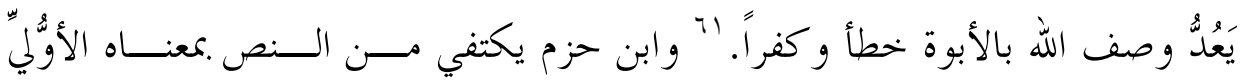

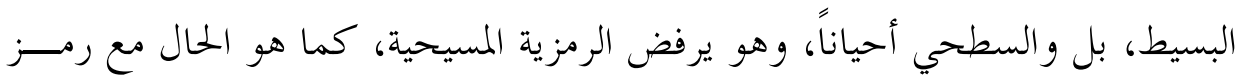

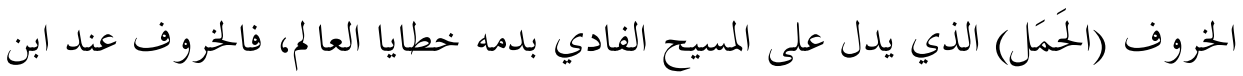

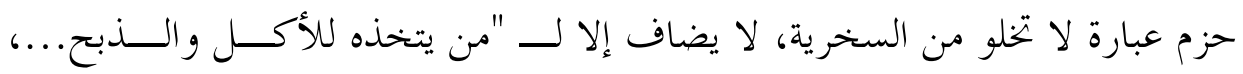

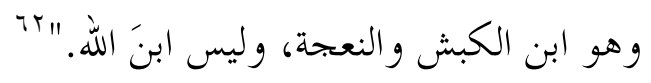

$$
\begin{aligned}
& \text { 10 المرجع السابق، صعه 1. }
\end{aligned}
$$

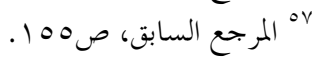

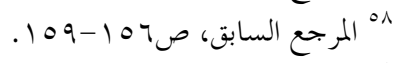

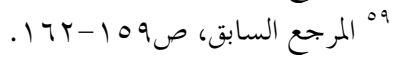

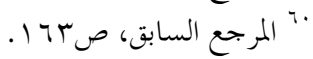

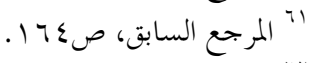

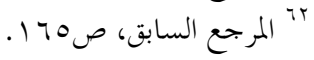


وينتقد الكاتب هذه النظرة الساخرة عند ابن حزم بقوله: "وهكذا يمرٌٌ ابن حــزم م

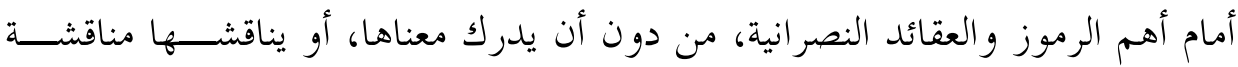

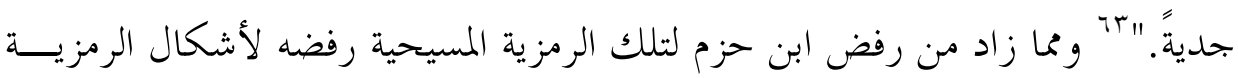

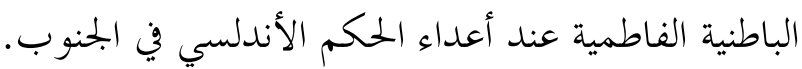

و وي دراسته لموقف النصرانية من العهد الجلديد، ركز ابن حزم على التبــاين بــين

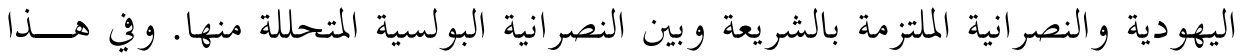

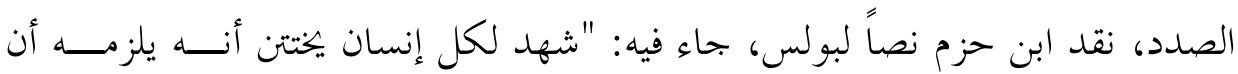

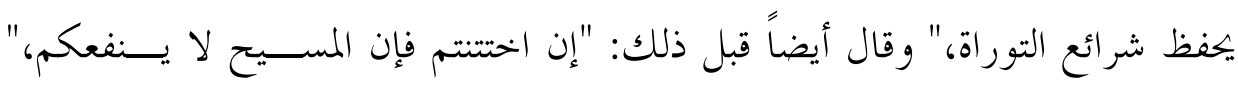
واستنتج ابن حزم من النص أن بولس يشرع لدينين مختلفين: "دين المختونين الملتـــمين بالتوراة، الذين لا ينفعهم المسيح، ودين الغرل غير الملتزمين بالتوراة، وهم فقط ينفعهم " المسيح.

ويأحذ الكاتب على ابن حزم نقده السابق، ويرى أن السياق العام للنص لا يفهم

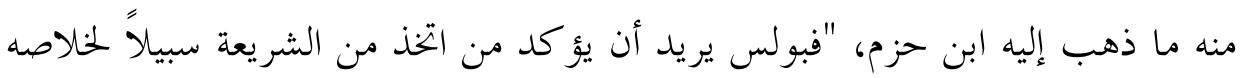

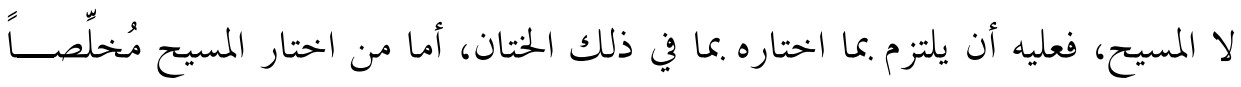

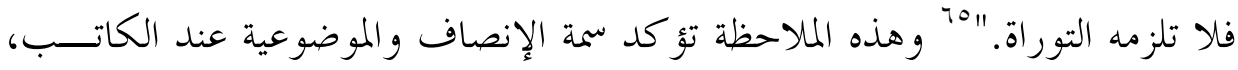
وقدرته على تقييم نقد ابن حزم ومراجعته وفق القراءة "الأحسن للنص" وليس القراءة

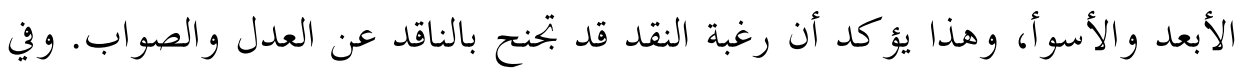

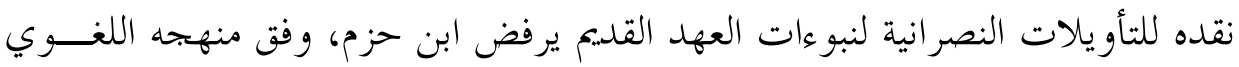
المنطقي لفهم النصوص -التأويل الرمزي- الذي يفسح البحال لفوضى تأويلية بتعل كل فريق يُوجِّه النص نحو وجهته الخاصة؛ فاليهود يرون فيها حلمهم المسيحاني بعودة أبحاد

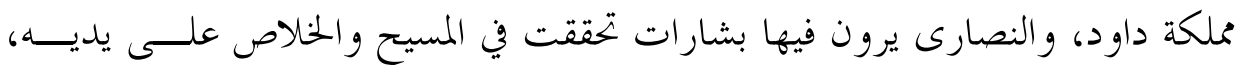

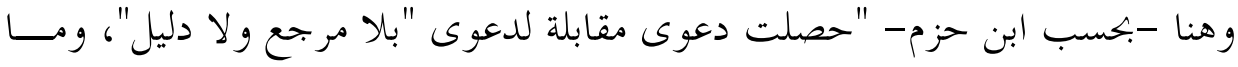




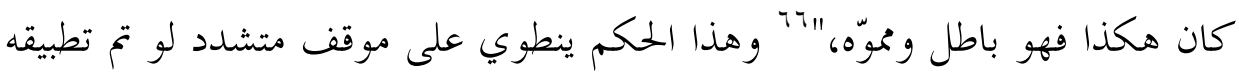

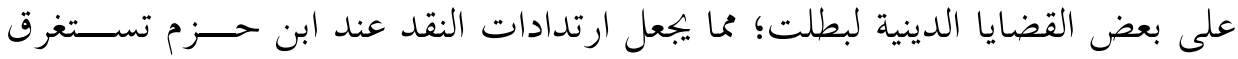

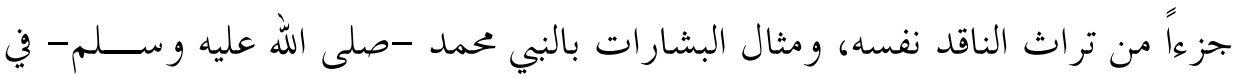
العهد القديم والجديد دليل على ذلك.

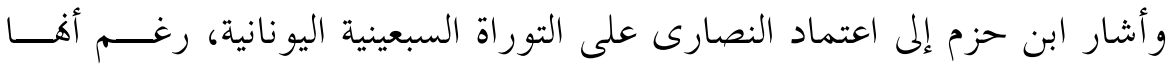

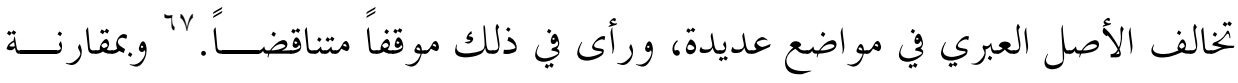

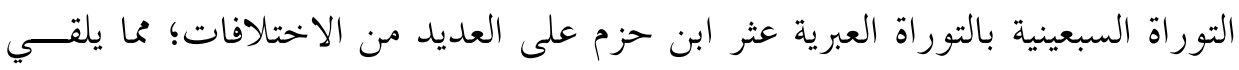

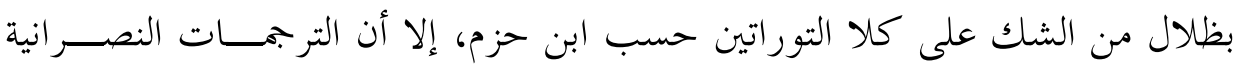

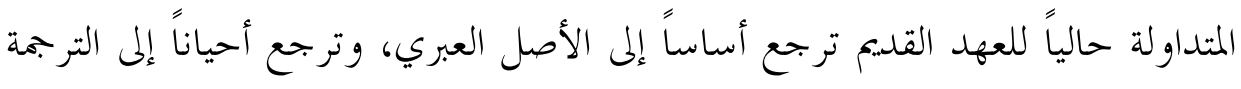

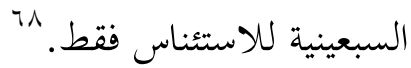

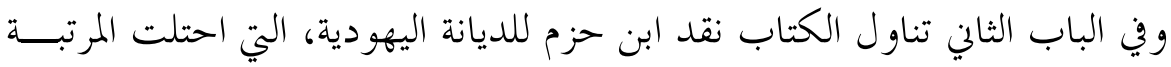

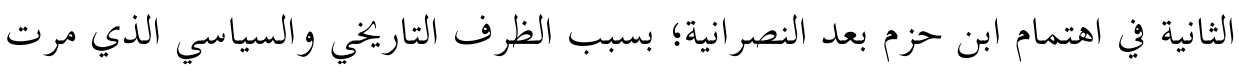

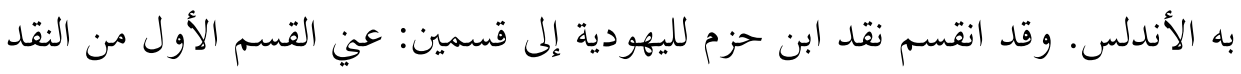

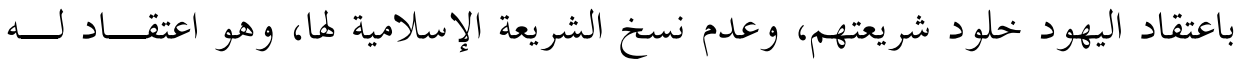

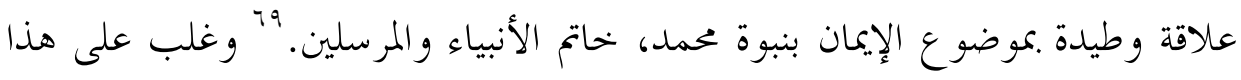

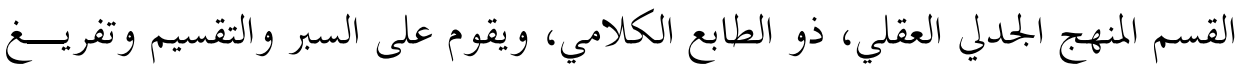
الاحتمالات وتنفيذها؛ قصد محاصرة الخصم و إفحامه.

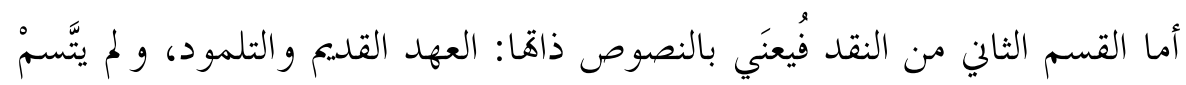

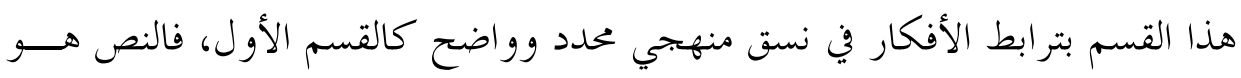

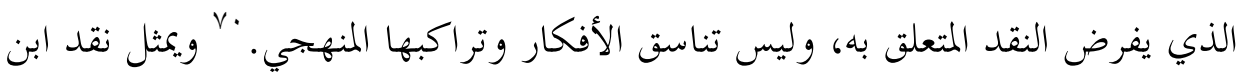

$$
\begin{aligned}
& \text { צ' المرجع السابق، صrV IV I. }
\end{aligned}
$$

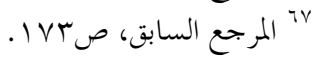

$$
\begin{aligned}
& \text { 1 }
\end{aligned}
$$

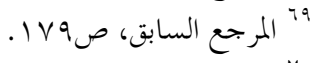

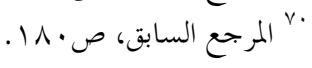


حزم للنصوص اليهودية جانب الجمدة والإضافة، فهو يعد أول من تنــاول النصــوص

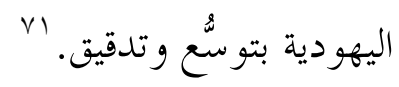

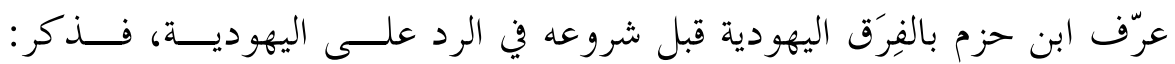

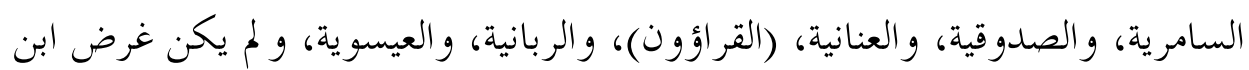

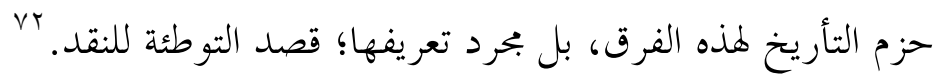

وقسّم ابن حزم اليهود من حيث مواقفهم من النسخ إلى فريقين: فريق قال بإبطال

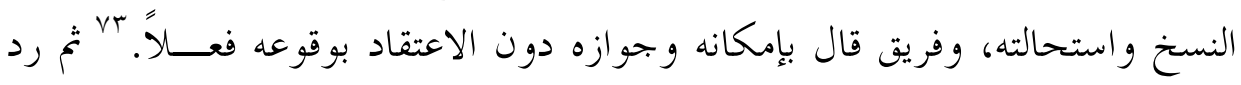

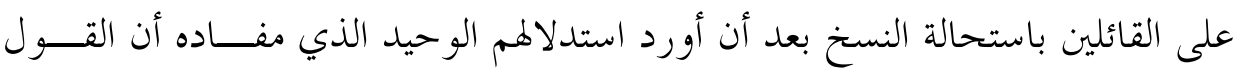

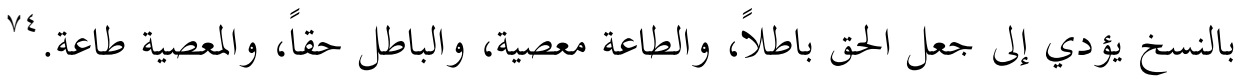
ويرد ابن حزم على هذا الاستدلال بأن النسخ "من صفات الله تعالى من جهة أفعالـــه.

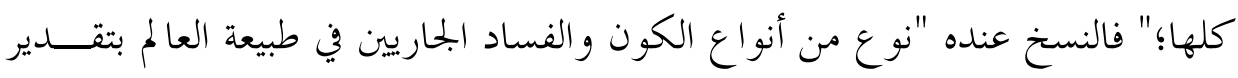
Vحالقه و مخترعه وملدبره

وبعد هذه النظرة الكونية المتعددة المستويات، التي ترى التحول و التغير من ســنـن

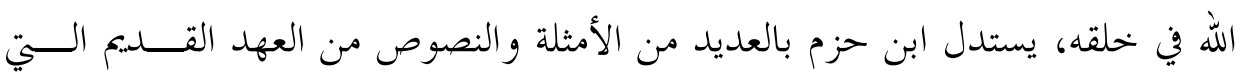
تؤ كد وقوع النسخ.

و يلاحظ الكاتب أن ابن حزم قد وقع في تناقض مع تعريفه الفقهي للنسخ عندما قال في أمثلته على الناسخ عند اليهود "كالعمل، هو عندهم مباح في الجمعة، حرام يوم

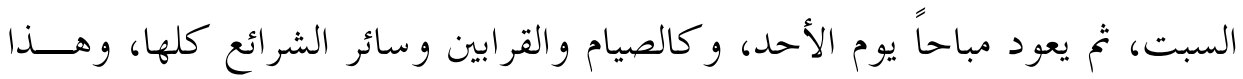

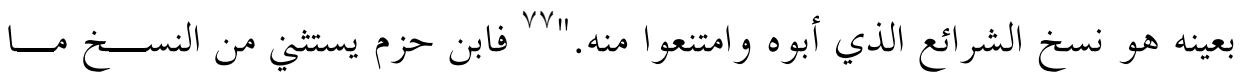

$$
\text { צr }
$$




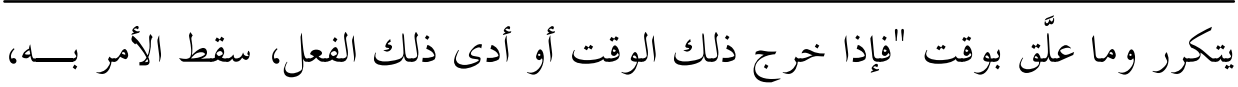

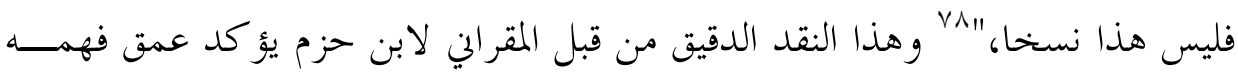

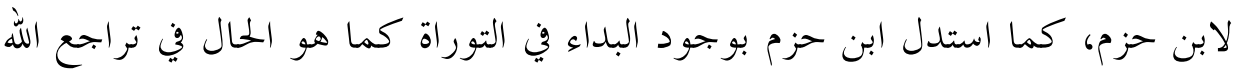

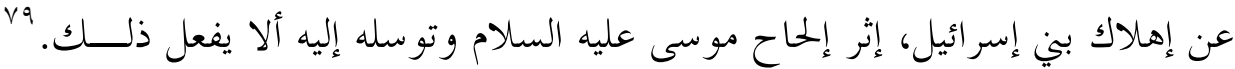

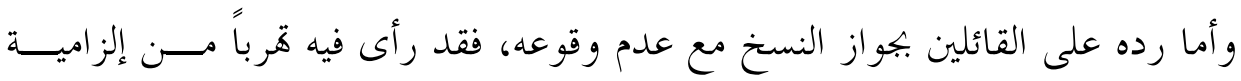
الإيمان بنبوة محمد صلى الله عليه وسلم. .

وفي الفصل الثاني تناول الكتاب تعريف النصوص اليهودية وترجمتــها، فتسـرف

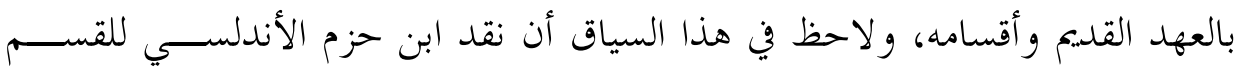

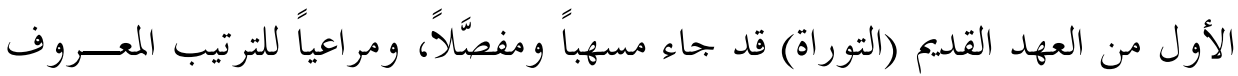

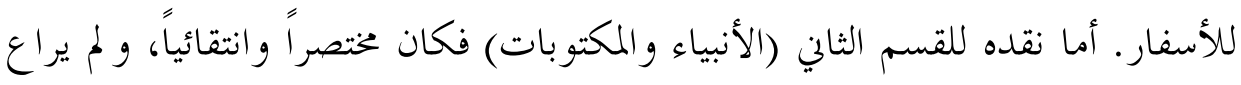

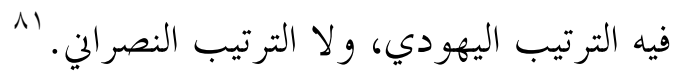

وأما نقد ابن حزم للتلمود والمدراش، فيلاحظ الكاتب عدم توسع ابن حسز فز في

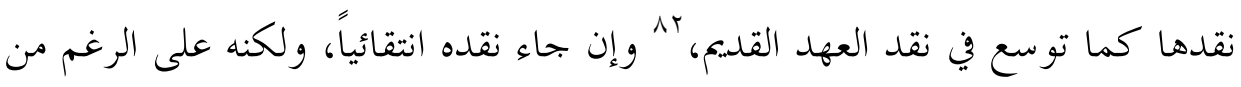

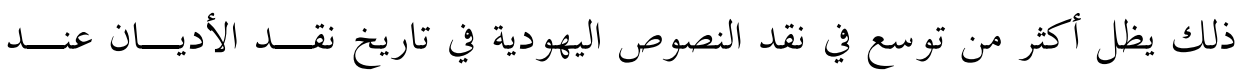

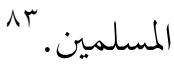

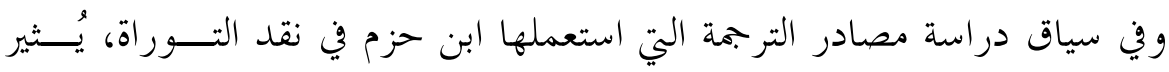

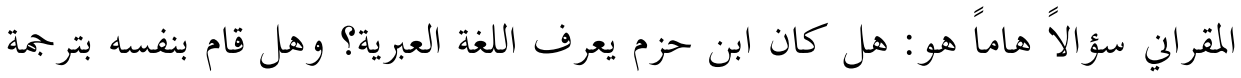

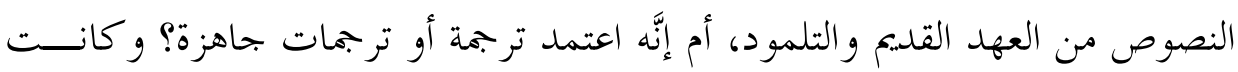

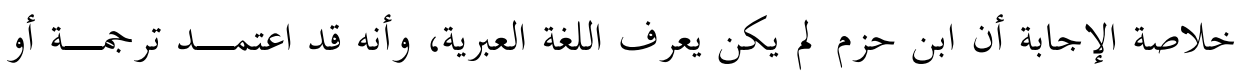

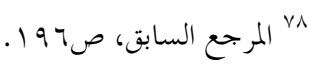

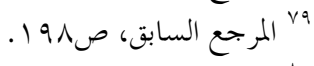

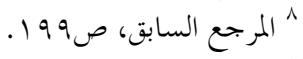

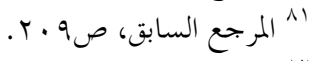

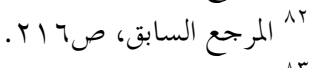

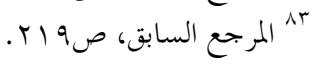




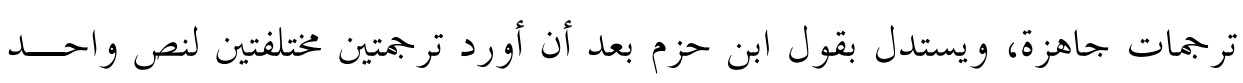

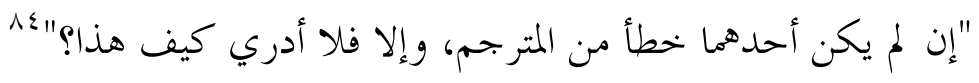
و أما الفصل الثالث، وهو "نقد النصوص اليهودية"، فقد جاء مُقسَّمَاً إلى قســمين رئيسين: أولمما يعنى بفحوى النصوص (النقد الداخلي)، و ثانيهما يعين بتاريخها (النقد

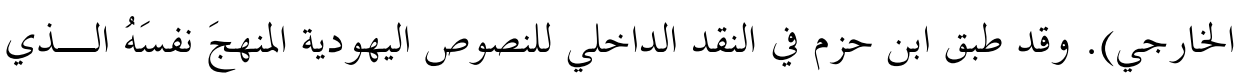

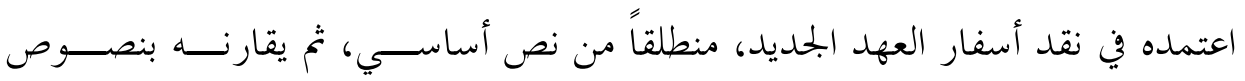

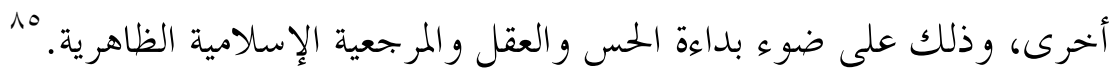

وفي نقده للنصوص اليهودية في موضوع الألوهية جاء بالنصوص التي يفيد ظاهرها

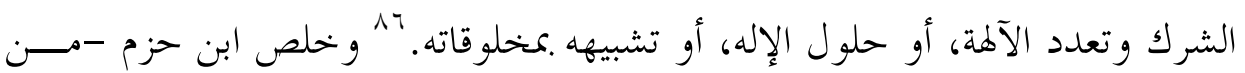

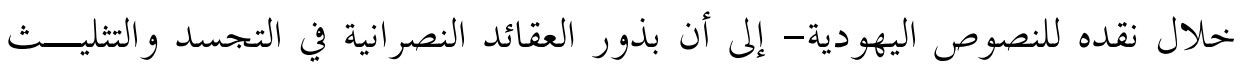

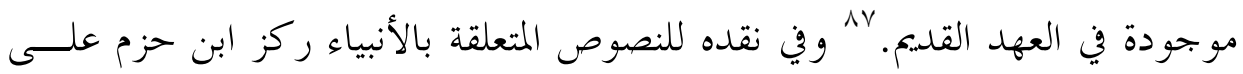

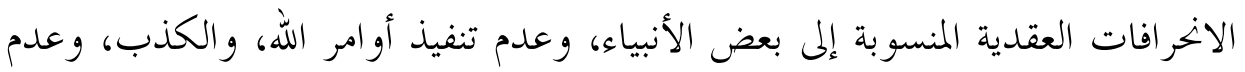

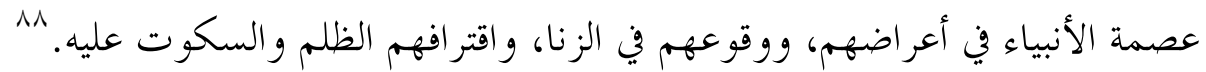
كما استخرج ابن حزم أخطاء حسابية في العهد القديع، سواءً في تقـــدير أعمـــار

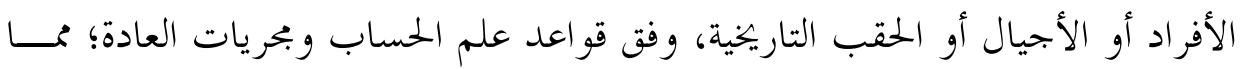

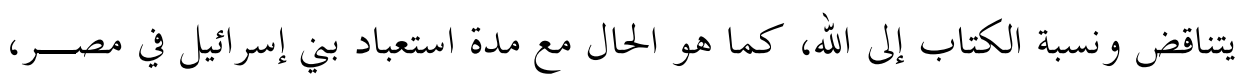

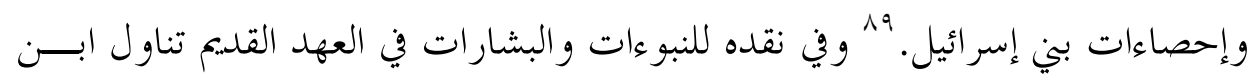

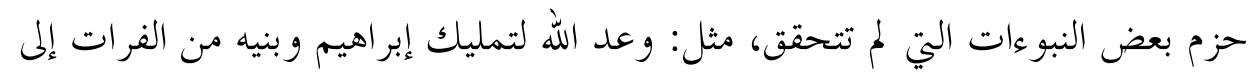

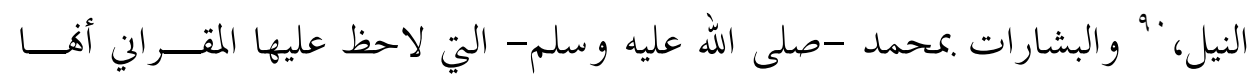

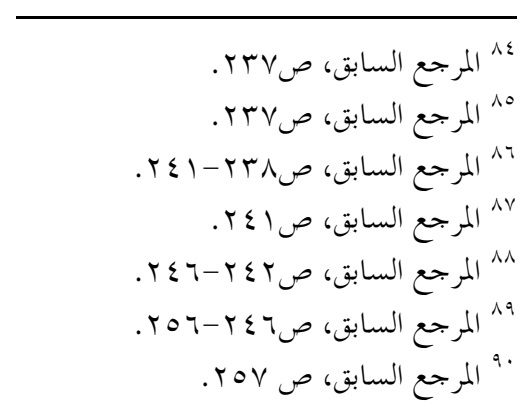


جاءت قليلة، وعلل ذلك بالمنهج "الظاهري، الذي ينشد الوضوح، وينفر من النصوص الرمزية الغامضة. "91"

وبالرغم من اتهام ابن حزم اليهود بتحريف التوراة؛ بسبب عــــم و جـــود تلـــك

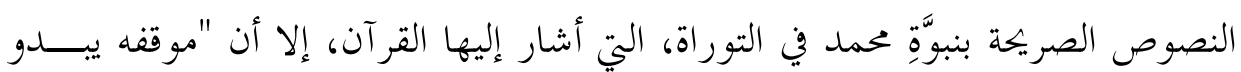
متناقضاً بين التشدد في رفض النبوءات التي يمكن أن تؤول لصالح اليهودية أو النصرانية،

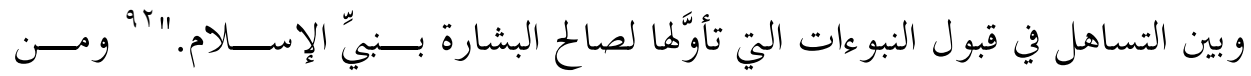

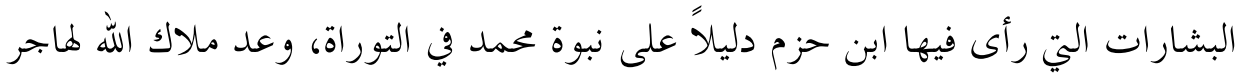

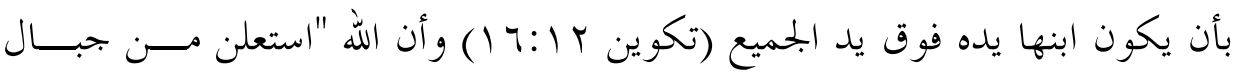

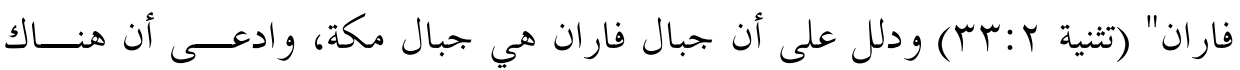
إجماعاً على أها كذلك، والواقع أن ليس هناك إجماع على ذلك ولك وفق المرجعية اليهودية و النصر انية.

وقد كان المقراني دقيقاً وموضوعياً إلى حد كبير عندما رأى بأن بعض النصــوص

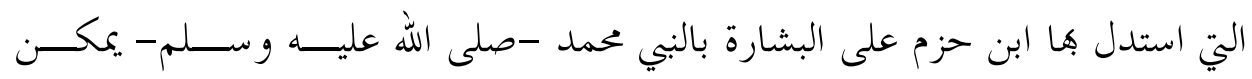

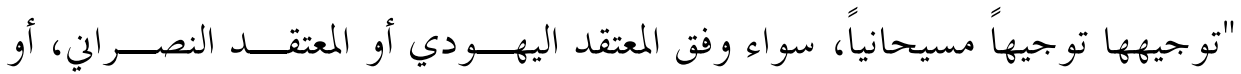

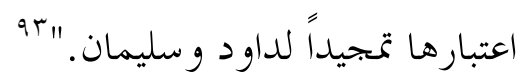

وفي الإشكالات الجغرافية التوراتية تناول الكاتب نقد ابن حزم لقول التوراة بـــأن

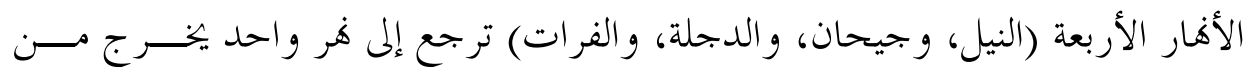

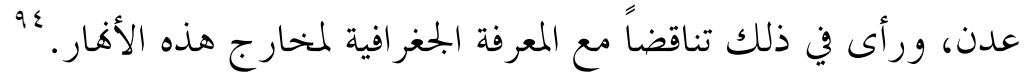
كما يُعَدُّ نقد ابن حزم بداية لإعادة النظر في المعارف الجغرافية للتوراة، وهي مـــن

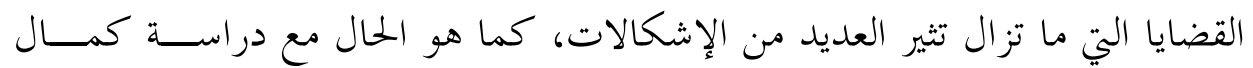
الصليي "التور اة جاءت من جزيرة العرب".

$$
\begin{aligned}
& \text { 19 المرجع السابق، ص ابحr. }
\end{aligned}
$$

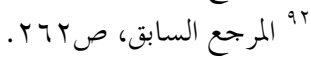

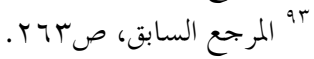

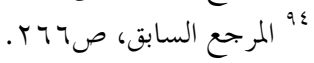


لكن، ثنمة ملاحظة ختم هها المقراني التناقضات الجغر افية للتوراة، وهي تُعبِِــر عــن

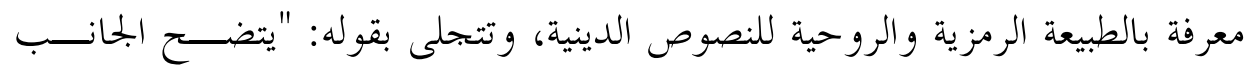

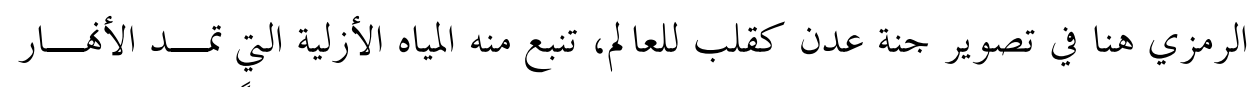

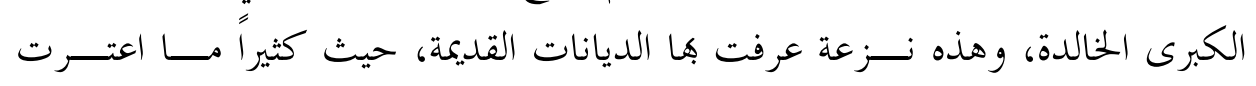

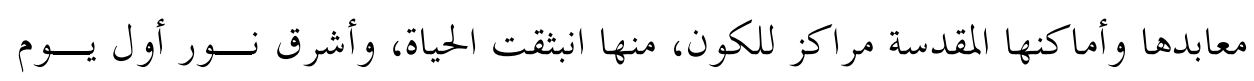

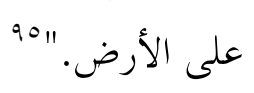
وفي النقد الخنارجي لأسفار العهد القديم حرص ابن حزم علــى إظهـــار وقتــوع

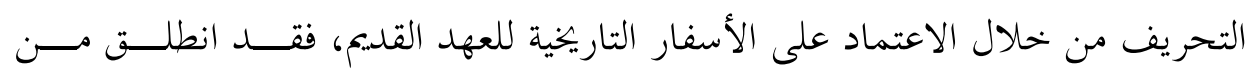

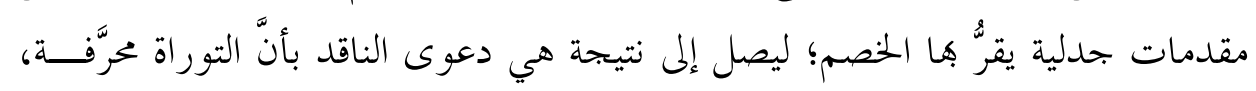

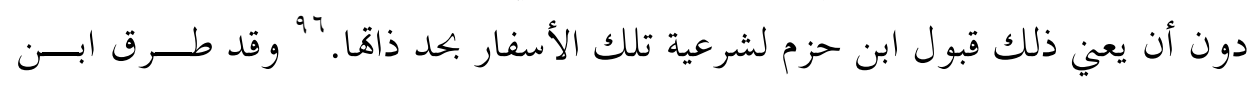

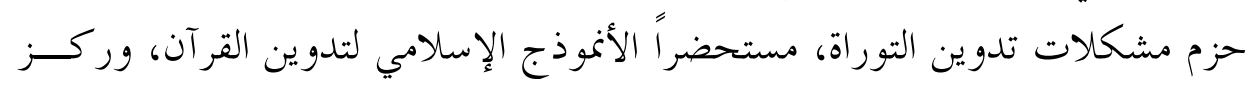
على إظهار الاضطرابات المختلفة التي رافقت المرحلة الفاصلة بين موسى وعزرا مما أثر

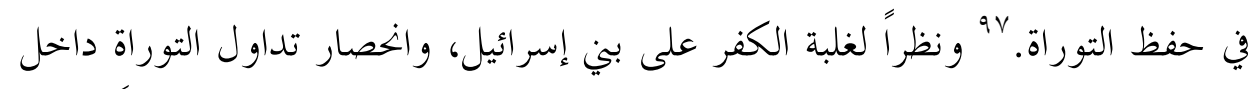

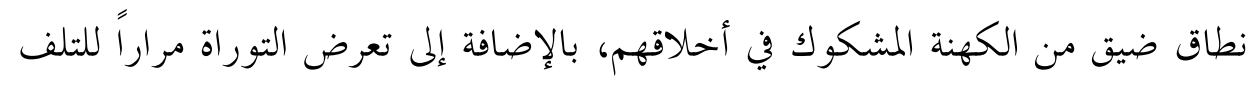

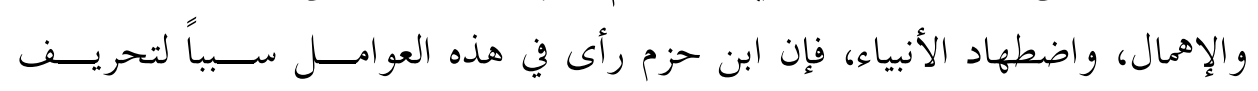
التوراة.

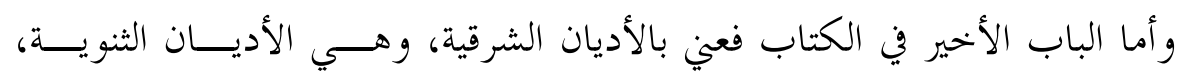
و البحوسية، و المزد كية، و الصابئة، و والمانوية، والديصانية، و المرقو نية، و البرهمية. و بـــالرغم

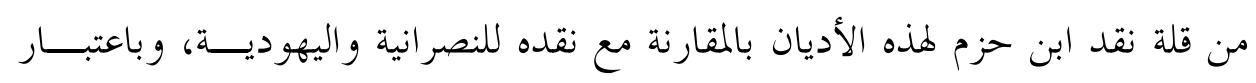

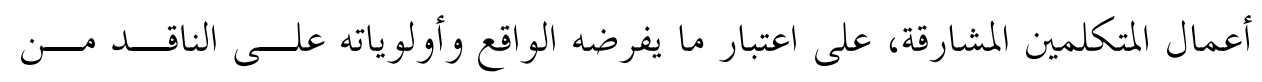

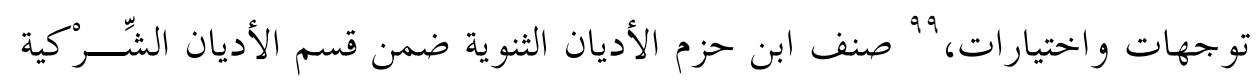

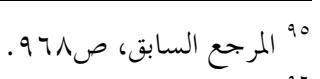

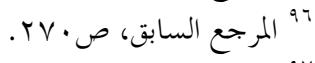

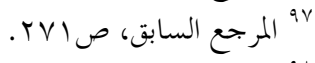

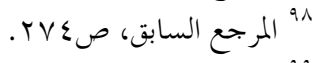

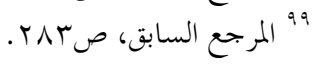


التي تقول بتعدد الآلهة، ثم قسمها (الثنوية) إلى قسمين: الأديان التي تمايز بــين العــــالم

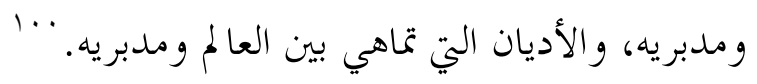

وجاء ضمن القسم الأول كل من المجوسية والصابئة، وبعد عرض الكاتب لتعريف

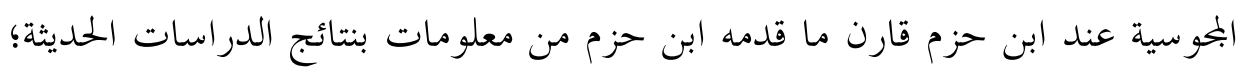

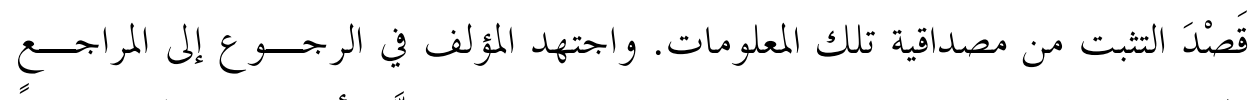

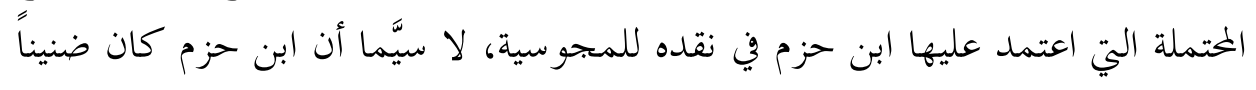

$$
\text { في ذكر مصادره. }
$$

وخلص المقراني إلى أن ابن حزم "كان قد أصاب حينما ذكر أن نظريسـة صــدور

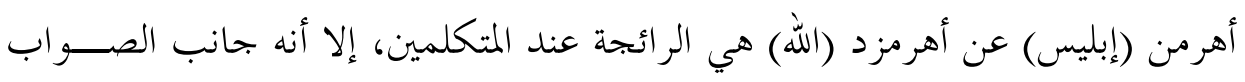

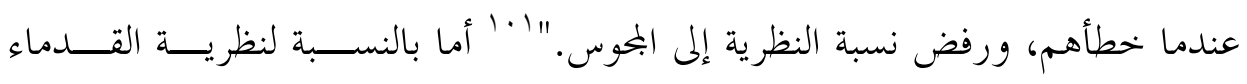

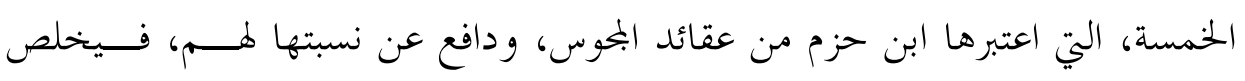

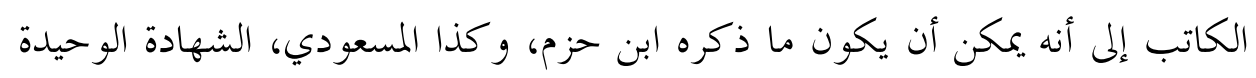

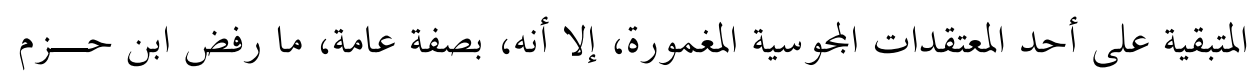

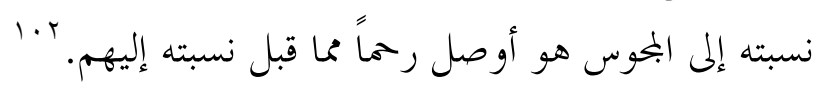

وأما المزدكية فلم يفصّل ابن حزم القول فيها، واكتفى بذكر نسبة تأسيســها إلى فئل

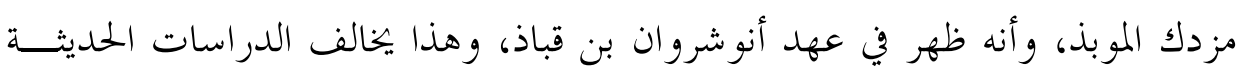

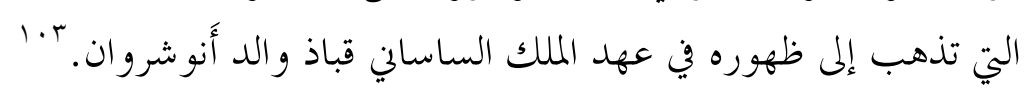

ويرى ابن حزم أن دين الصابئة هو أقدم الأديان وأعمها على وجه الأرض. وأنــهـ

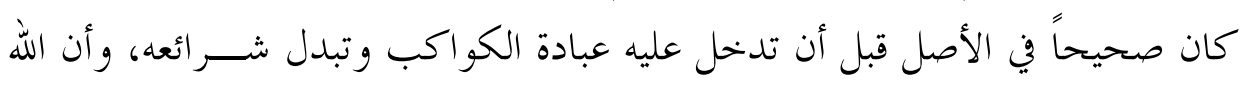

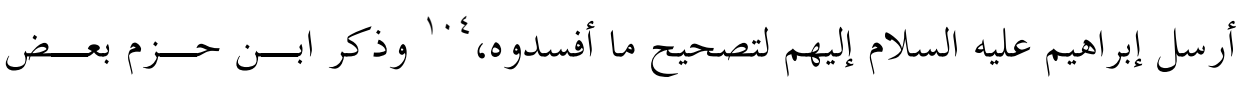

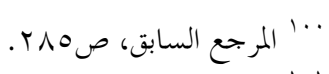

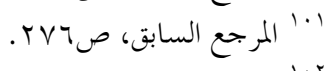

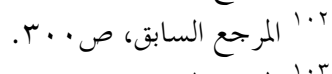

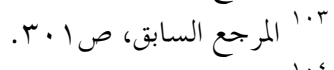

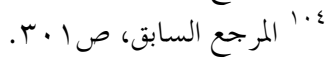




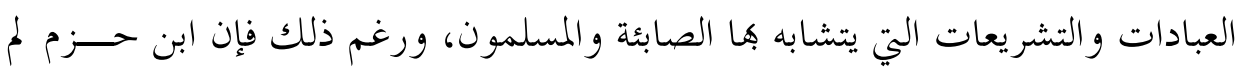

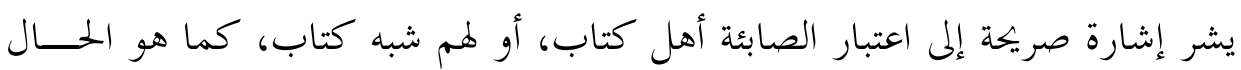
مع البحوس.

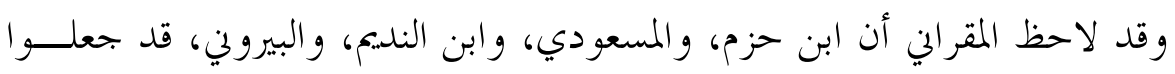

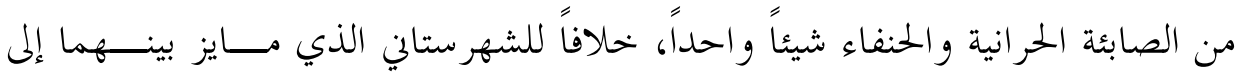

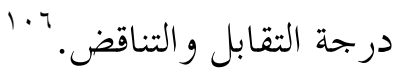

وأما المجموعة الثانية من الأديان الثانوية فهي الأديان التي تماهي بين العالم ومدبريه،

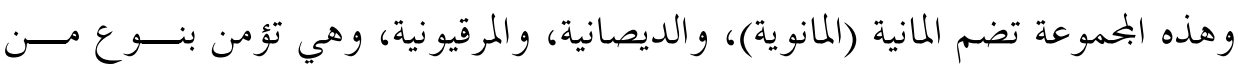

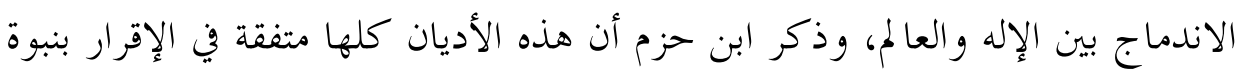

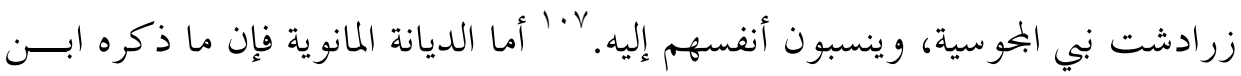

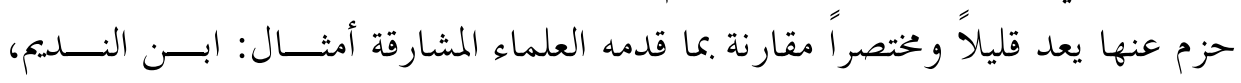

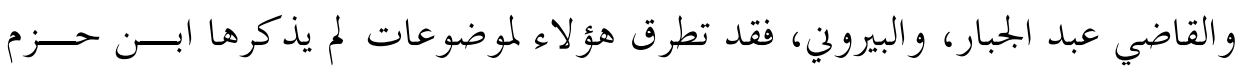

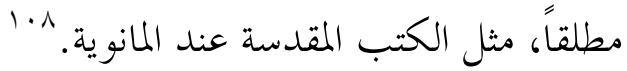

ويلتمس المقراني الأعذار لابن حزم في قلة المعلومات وبعض الأخطاء التي وقع فيها

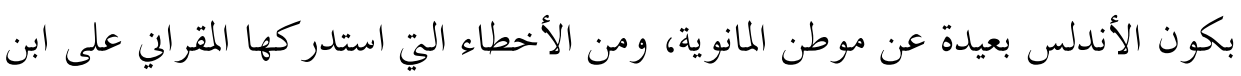

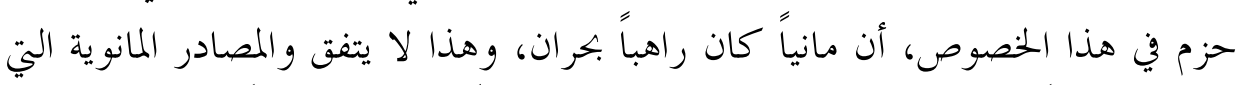

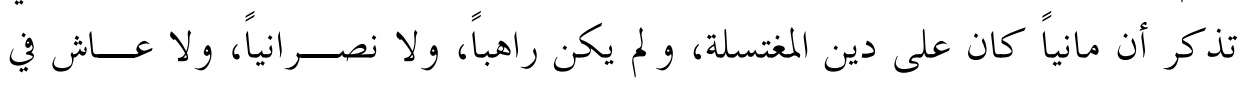
حران.

وعلى نحو قريب مما عالج به ابن حزم المانوية، تعامل مع الديصانية والمرقيونية، إلا إلا

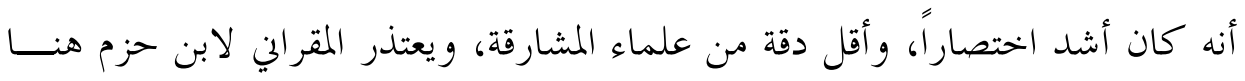
كما اعتذر له في المانوية.

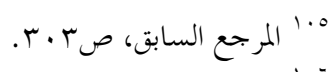

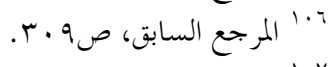

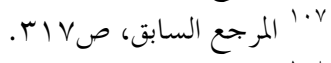

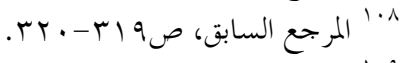

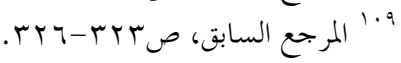


وتأثر نقد ابن حزم للبرهمية التي تمثل الديانة القومية للهنود بقلة المعلومات حـــــل

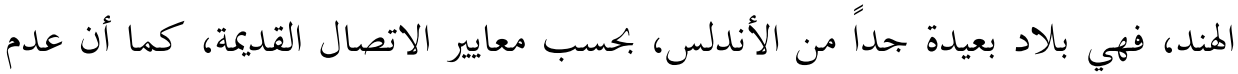
وجود أتباع لهذه الديانة خارج النطاق الحضاري الهندي قد أسهم في شح المعلومـــات

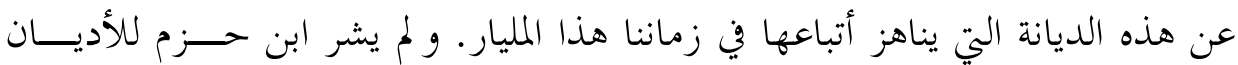

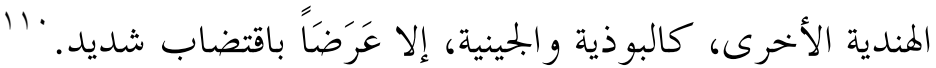

وأخذ المقر اني على نقد ابن حزم للبرهمية بعض الملاحظات، أهمها: ما ذهب إليــه

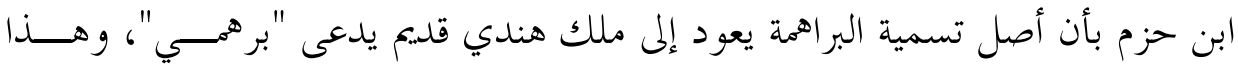

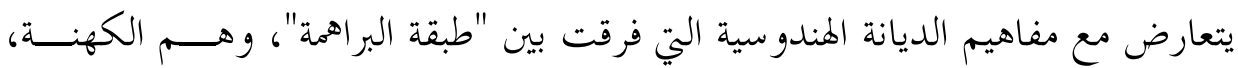
وبين طبقة "الكشاتريا"، وهم الحكام و المحاربون.

وأما العقائد الهندوسية فقد أغفل ابن حزم ذكر عقيدة تناسخ الأرواح التي هــي

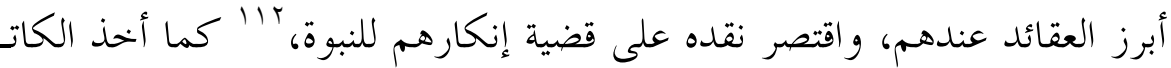
على ابن حزم وصفه للبراهمة بأهم موحدون لأن السمة الأبرز عندهم هي تعدد الآلهة،

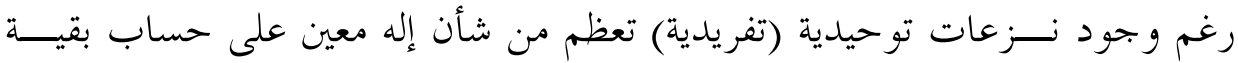

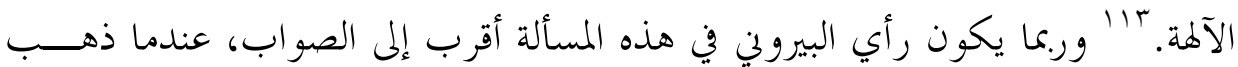
إلى أن التوحيد هو عقيدة الخواص من الهنود، أما الشرك فهو عقيدة العوام منهم، الذين

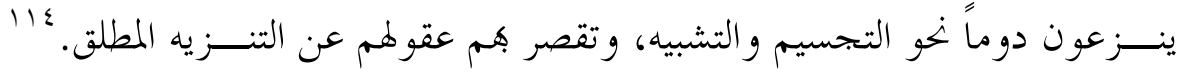
ويمكن تقسيم نقد ابن حزم للأديان الشرقية إلى محورين أساسيين: أولمما يــدور حول التثنة، وثانيهما يدور حول النبوة.

و يلاحظ الكاتب أن ابن حزم قد ترك نقد الشرائع؛ لأهفا لا تدرك عنده بالعقـــل؛

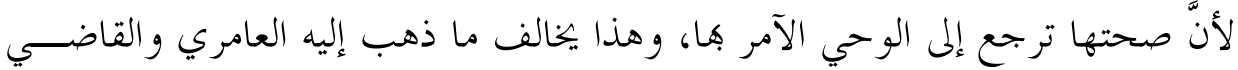

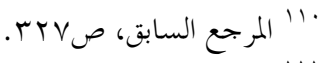

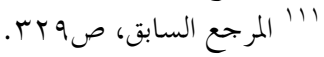

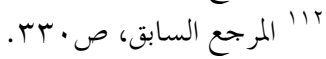

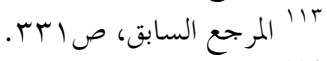

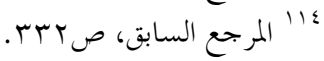




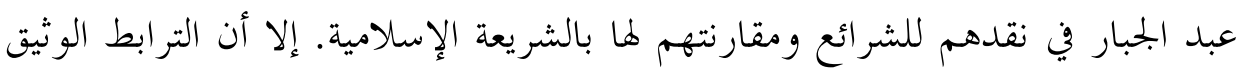

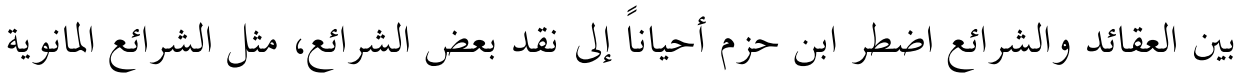
المتعلقة بتحريم النكاح.

يرد ابن حزم على استدلال الثنوية بأن الحكيم لا يفعل الشر ولا العبث، و.بــــــأن

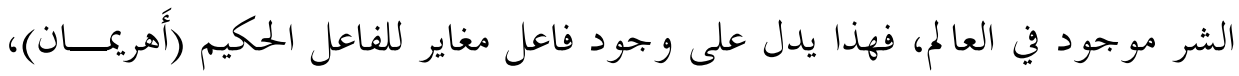

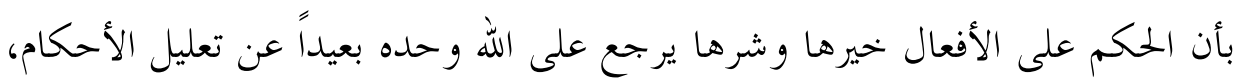

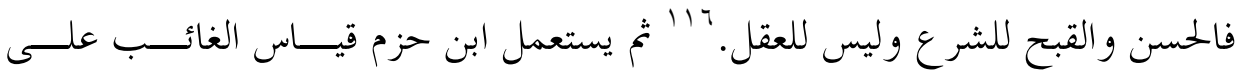

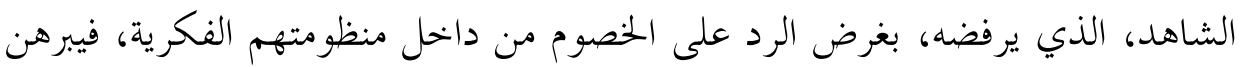

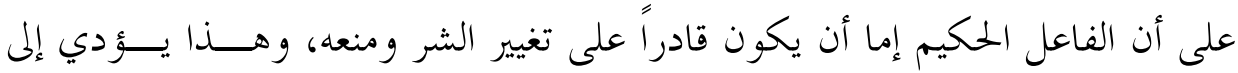

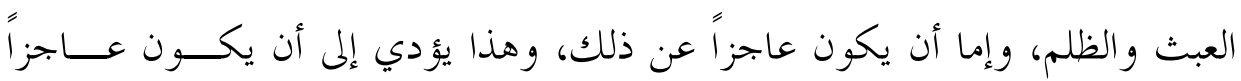
وضعيفاً.

وأما رد ابن حزم على الأديان المماهية بين العالم ومدبريه، فقد أحال فيه ابن حزم

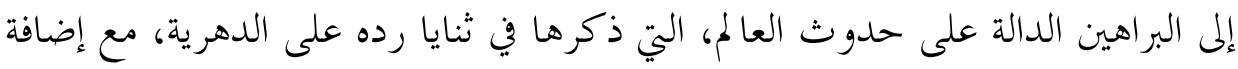

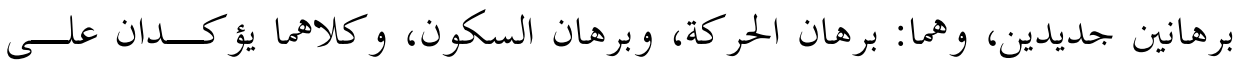

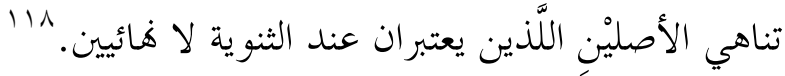

و انتقد ابن حزم قول البراهمة بأن بعثة الرسل تتنافن مع حكمة الله تعالى، ورأى أنَّه

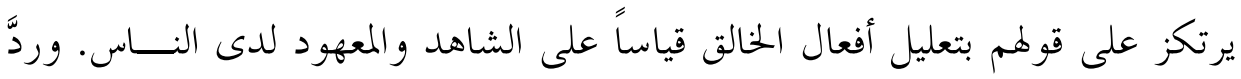

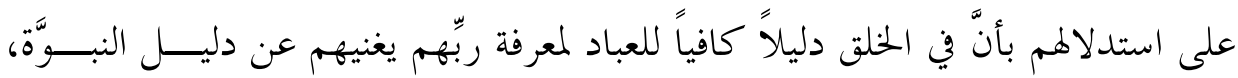

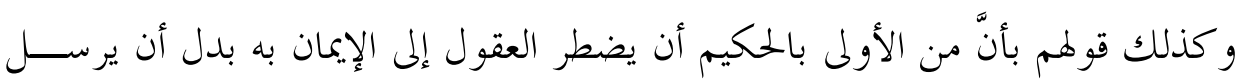
الرسل. 119

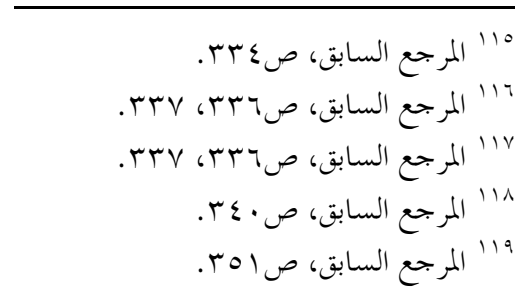


ويخلص الكاتب بعد ذكر رد بن حزم على استدلالات البرهميــة إلى أنَّ ردَّ ابــنـ

حزم ينطوي على أنموذج و اضح على الارتباط الوثيق بين النقد والأصــــل المرجعيــة

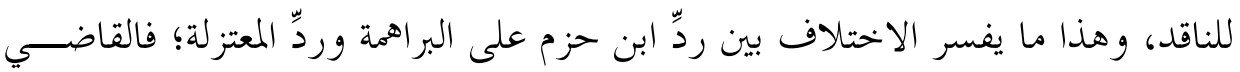

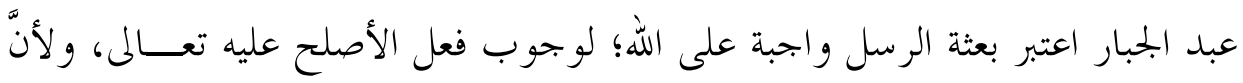

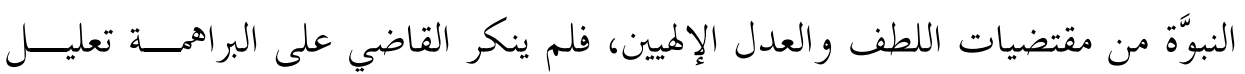

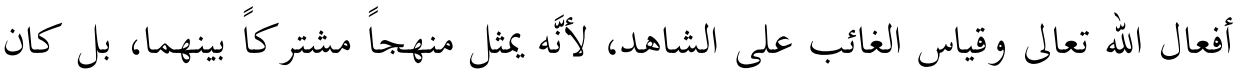
الخلاف في كيفية تطبيق المنهج.

وأما رده على منكري بعض النبوات، فقد جاء في باب "الكلام علــى اليهـــود، وعلى من أنكر التثليث من النصارى، ومذهب الصابئين، ومن أقر بنبوة زرادشت من المحوس، وأنكر من سواه من الأنبياء." يعترف ابن حزم بنبوة زرادشت، وهو بــــلك يسبق غيره من العلماء المسلمين الذين أقروا بإمكانية الاعتراف بنبوة بعض الشخصيات الدينية السابقة على بعثة النبي، كما هو الحال مع الشيخ عبد السلام الرامبوري، الذي قال بنبوة بوذا في الهند. وأقام ابن حزم أدلته على جواز نبوة من جاء قبل البي محمد صلى الله عليه وسلم- وثبتت له المعجزة بالتواتر عند المجوس، وأن ما نسب إليه مـــن

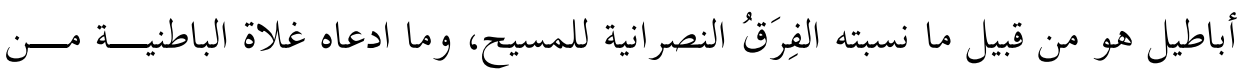
أباطيل على القر آن، واستدل بأخذ البي صلى الله عليه و سلم الجزية من الجموس وأقوال

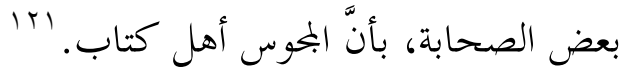

ويتمثل الرد الأساسي الذي و جهه ابن حزم إلى الأديان المنكرة لنبوة محمد -صلى

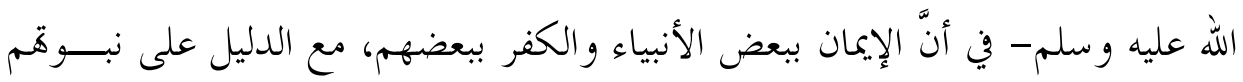

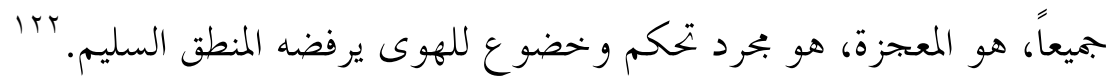


وفي ردِّه على عقيدة تناسخ الأرواح قدَّم ابن حزم تصــنيفين خخــلفين للقـــائلين

بتناسخ الأرواح: أمَّا التقسيم الأول فجاء بحسب الاختلاف في موضوعات التناســـخ القائلون بوقوع التناسخ بين أفراد الأنواع المختلفة، والقائلون بوقوعه ضمن أفراد النوع الواحد. و أما التقسيم الثاني فجاء بحسب ديانة القائلين بالتناسخ، من قال بالتناسخ من

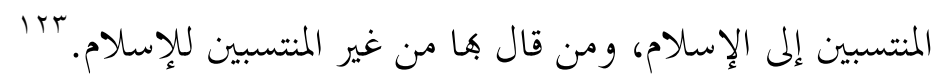

ويلاحظ الكاتب أنَّ معلومات ابن حزم عن القائلين بالتناسخ: من غير المســلمين

ضئيلة وغامضة، على عكس معرفته بالقائلين بالتناســـخ مـــن المنتســـبين إلى الــــين الإسلامي. گrا وقد رد ابن حزم على القائلين بالتناسخ من المنتسبين إلى الإسلام، مبيناً

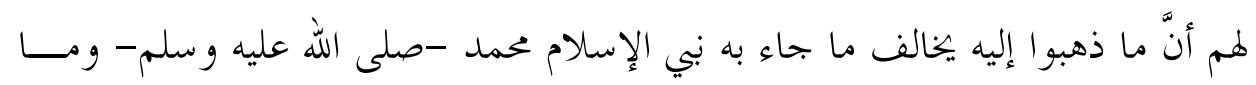

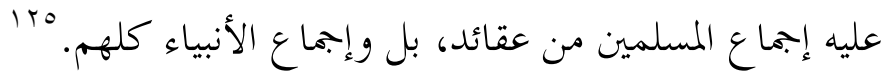
أمَّا القائلون بالتناسخ بين الأنواع من الدهرية، فردَّ عليهم ابن حزم بأنَّ الأنـــواع ثابتة لا تستحيل بعضها إلى بعض، فلكل نوع فصل خحاص بأرو احه لا يتعداه. بrا' و لم

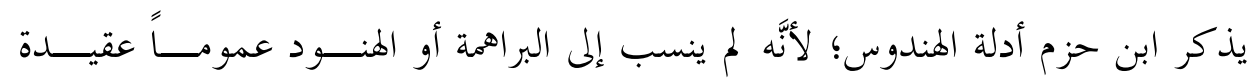

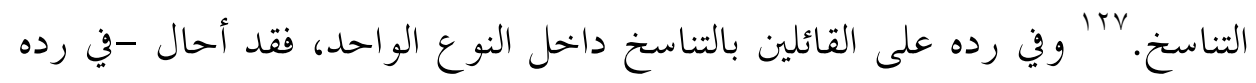

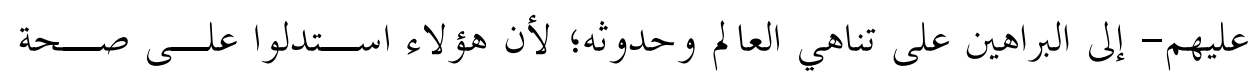

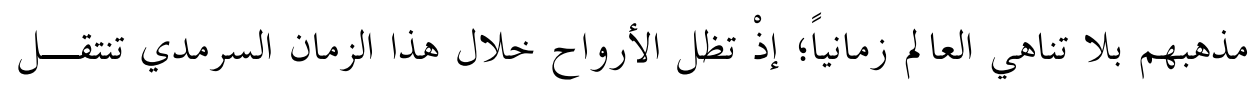

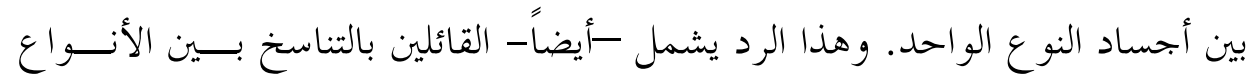

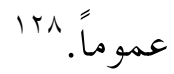

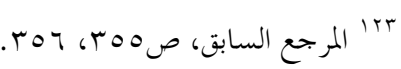

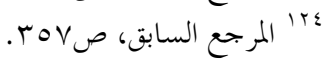

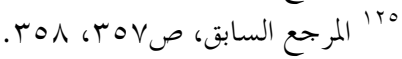

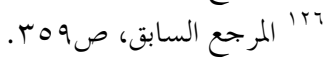

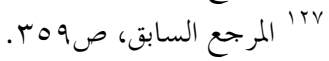

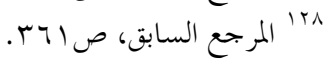




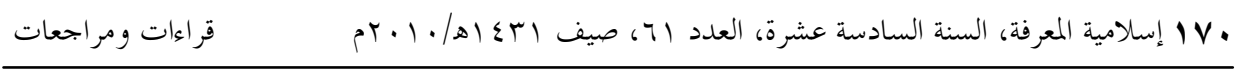

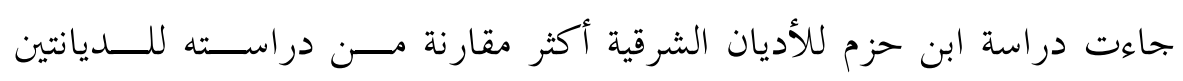

النصر انية و اليهودية، و من مسوغات هذا الأمر محاولة ابن حزم تقريسـبـ فهـــم تلـــك

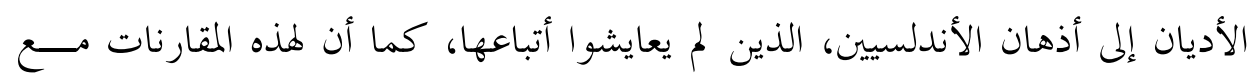
بعض الفرق الإسلامية أبعادها داخل الأندلس وجوارها. وفي الخاتمة يمكن القول: إنَّ هذه الدراسة قد بتحاوزت معظم الدراسات الســابقة

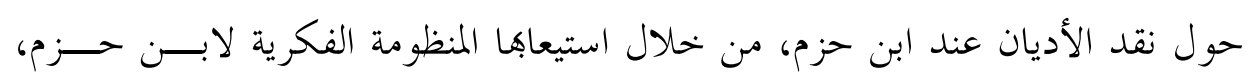

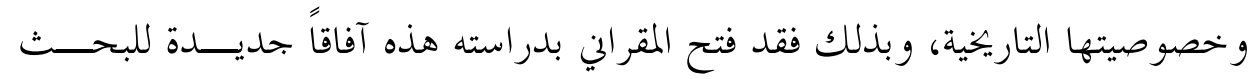
العلمي المتخصص في دراسة "نقد الأديان" ومر اجعَتِّهِ في تراثنا الإسلامي. 